\title{
Reconciling food security and biodiversity conservation: participatory scenario planning in southwestern Ethiopia
}

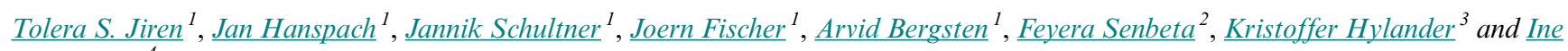
Dorresteijn $^{4}$

\begin{abstract}
Social-ecological systems are complex and involve uncertainties emerging from interactions between biophysical and social system components. In the face of growing complexity and uncertainty, stakeholder engagement with the future is important to proactively manoeuvre toward desirable outcomes. Focusing on the interrelated challenges of food security and biodiversity conservation, we conducted a participatory scenario planning exercise in a rural landscape in southwestern Ethiopia. We involved 35 stakeholder organizations in multiple workshops to construct causal loop diagrams, elicit critical uncertainties, and draft scenario narratives. Jointly, we developed four plausible future scenarios for the studied landscape: (1) gain over grain: local cash crops; (2) mining green gold: coffee investors; (3) coffee and conservation: a biosphere reserve; and (4) food first: intensive farming and forest protection. These scenarios differ with respect to their main social-economic dynamics as well as their food security and biodiversity outcomes. Importantly, three of the four scenarios, i.e., all except "coffee and conservation: a biosphere reserve," focused on increasing efficiency in agricultural production through intensification, specialization, and market integration. In contrast, "coffee and conservation: a biosphere reserve" was driven by agroecological production methods that support diversified livelihoods, a multifunctional landscape, maintenance of natural capital, a governance system that supports local people, and social-ecological resilience. Similar agroecological trajectories have been advocated as desirable for sustainable development in numerous other smallholder farming systems worldwide. Given fewer trade-offs and better equity outcomes, it appears that an agroecological development pathway stands a good chance of generating synergies between food security and biodiversity conservation. Pathways prioritizing agricultural efficiency, in contrast, are more likely to degrade natural capital and cause social inequity.
\end{abstract}

Key Words: agroecology; drivers of change; future scenarios; intensification; rural landscapes; social-ecological system; stakeholder participation

\section{INTRODUCTION}

Many agricultural landscapes in the Global South face the two interlinked challenges of improving food security while also halting biodiversity decline. Despite a continued increase in global food production over the last years, one in nine people are still considered food insecure (Godfray et al. 2010, FAO 2018). At the same time, the expansion and intensification of agriculture has contributed to biodiversity loss (Foley et al. 2005). The urgency of reconciling food security and biodiversity conservation is greater than ever given increasing pressures from population growth, natural disasters, and climate change. This has been globally recognized by including aims on limiting food insecurity and biodiversity loss in the United Nations Sustainable Development Goals (UN 2015a). Guidance on how to reconcile these two aims in actual landscapes has, however, been scarce (Fischer et al. 2017). Such guidance in turn should consider that food security and biodiversity conservation are intimately connected through land use practices, livelihoods, and governance arrangements (Chappell and LaValle 2011, Sunderland 2011).

In this paper we approach these complex and interrelated issues through a social-ecological, participatory case study in southwestern Ethiopia. Notably, integrating food security and biodiversity conservation poses ecological questions (Green et al. 2005, Fischer et al. 2008, Edwards et al. 2010, Phalan et al. 2011) as well as agronomic ones (Balmford et al. 2005, Rudel et al. 2011, Lemessa et al. 2015). Further, there are also questions related to actor constellation and governance mechanisms (Folke et al. 2003, Ostrom 2009, Berkes 2017), equity (Nyéléni Declaration 2007, Pimbert 2009, Fischer et al. 2017, Wittman et al. 2017), as well as numerous feedbacks that cause path dependencies in development (Fischer et al. 2017). Importantly, all of these features are interdependent and involve multiple sectors interacting across multiple scales (Chappell and LaValle 2011). Many previous studies approached food security and biodiversity as partly separate issues (Glamann et al. 2017, Wittman et al. 2017), paying limited attention to the temporal dimensions of integrating the goals of food security and biodiversity conservation. Here, we used participatory scenario planning to provide insights on the future integration of the goals of food security and biodiversity conservation. Moreover, our paper provides insights on the methods for participatory scenario development, such that it can help to induce collective action toward achieving a desired future.

Southwestern Ethiopia is an interesting system for answering such questions because it shares many of the social-ecological system properties of other rural landscapes in the Global South, including rapid population growth (OBFED 2012, FAO 2018), ecosystem degradation driven by land use change (Tadesse et al. 2014), and a high level of horizontal institutional fragmentation (Gatzweiler 2005), that is, poor coordination across administrative boundaries and also between different sectors within the same administrative unit (Jiren et al. 2018a). Similarly, the challenges around food security, biodiversity conditions, and

${ }^{1}$ Faculty of Sustainability, Leuphana University Lueneburg, Lueneburg, Germany, ${ }^{2}$ Center for Environment and Development Studies, College of Development Studies, Addis Ababa University, Addis Ababa, Ethiopia, ${ }^{3}$ Department of Ecology, Environment and Plant Sciences, Stockholm University, Stockholm, Sweden, ${ }^{4}$ Copernicus Institute of Sustainable Development, Utrecht University, Utrecht, The Netherlands 
associated governance mechanisms are not unlike those in many other developing countries. People in southwestern Ethiopia are food insecure by international standards, although better-off than in the drier parts of the country (CSA/WFP 2014). From a biodiversity perspective, southwestern Ethiopia hosts an important share of global biodiversity (Mittermeier et al. 2011), is the origin of Coffea arabica, and supports the remaining Afromontane forests of Ethiopia (Chilalo and Wiersum 2011). However, biodiversity loss has been increasing over time (Gove et al. 2008, Hylander et al. 2014, Aerts et al. 2017). In terms of governance, the landscape is characterized by a hierarchical governance structure with government organizations being dominant, high institutional instability, and conflicting development and conservation policies (Jiren et al. 2018a). In the last two decades, the country has pursued several different policy directions ranging from the promotion of smallholder-based diversified agriculture (MOFED 2003) to investor-based commercial and industrial farming (Gebreselassie 2006), and more recently to building a climate resilient green economy that primarily seeks agricultural intensification (Federal Democratic Republic of Ethiopia 2011, Brems et al. 2015).

Given uncertainties in governance, and rapid social-ecological change, it is important for local stakeholders to engage with possible development trajectories in order to build adaptive capacity and generate shared visions for the future (Freeth and Drimie 2016). To this end, we conducted a visioning exercise, namely participatory scenario planning, with a wide range of local stakeholders. Participatory scenario planning is a method that engages researchers, community, and other stakeholders with the aim to elicit plausible future trajectories and, in turn, navigate uncertain futures in complex systems. Participatory scenario planning helps to identify important uncertainties and driving forces that shape current and future changes (Daconto and Sherpa 2010, Hanspach et al. 2014, Oteros-Rozas et al. 2015). Four specific questions guided our study: (1) What are drivers of socialecological change and how do they interact? (2) What are plausible future development trajectories or scenarios for the region? (3) How do these scenarios influence outcomes related to food security and biodiversity conservation? (4) How do stakeholders perceive the overall scenario development process and its contribution in terms of coordinating action toward creating a desired future? We discuss our findings with respect to general themes that are relevant to the future of rural landscapes around the world, focusing on social-ecological dynamics and actor and governance constellations that can help to harmonize food security and biodiversity conservation.

\section{METHODS}

\section{Study area}

The study was conducted in Jimma zone, Oromia regional state, southwestern Ethiopia. The population of Jimma zone is approximately 3.1 million people, $10 \%$ of Oromia's population, on $5 \%$ of Oromia's land (OBFED 2012). Smallholder farmers account for $89 \%$ of the zonal population (OBFED 2012). Within Jimma zone, we selected three broadly representative woredas, i.e., districts, for in-depth investigation, namely, Gumay, Gera, and Setema (Fig. 1). These woredas were selected because they capture the ecological and social diversities of the area including gradients in accessibility by road, and they consist of lower, medium, and large population sizes compared to the average population size of districts in Jimma. In addition, the three woredas are located across altitudinal gradients of coffee and food crop production. In Gumay woreda, coffee production is relatively intensive, while Gera woreda is known for its forest cover and the production of coffee, honey, and cattle farming. Setema woreda is primarily a food crop production area. Moreover, the three woredas also differ in terms of accessibility to social infrastructure. Gumay has relatively better access to health care, markets, and roads, while Gera has medium accessibility and Setema has the least access to social infrastructure. Within each of the three woredas, we purposively selected one kebele, i.e., municipality, namely Kuda Kufi, Difo Mani, and Kella Hareri. The selection of kebeles followed similar criteria as the selection of woredas. For instance, Kuda Kufi is a cereal production kebele with limited forest cover, while Kella Hareri is found in the coffee production altitude with dense forest cover. People in the study area mainly produce diversified crops, but the majority of the people are food insecure (CSA/WFP 2014).

Fig. 1. Map of the study area showing the three woredas (districts), the three kebeles (municipalities), forest cover, and access to road infrastructure. Kella Hareri is in the coffee altitude with high forest cover whereas Kuda Kufi and Difo Mani have little forest cover but better access to road infrastructure.

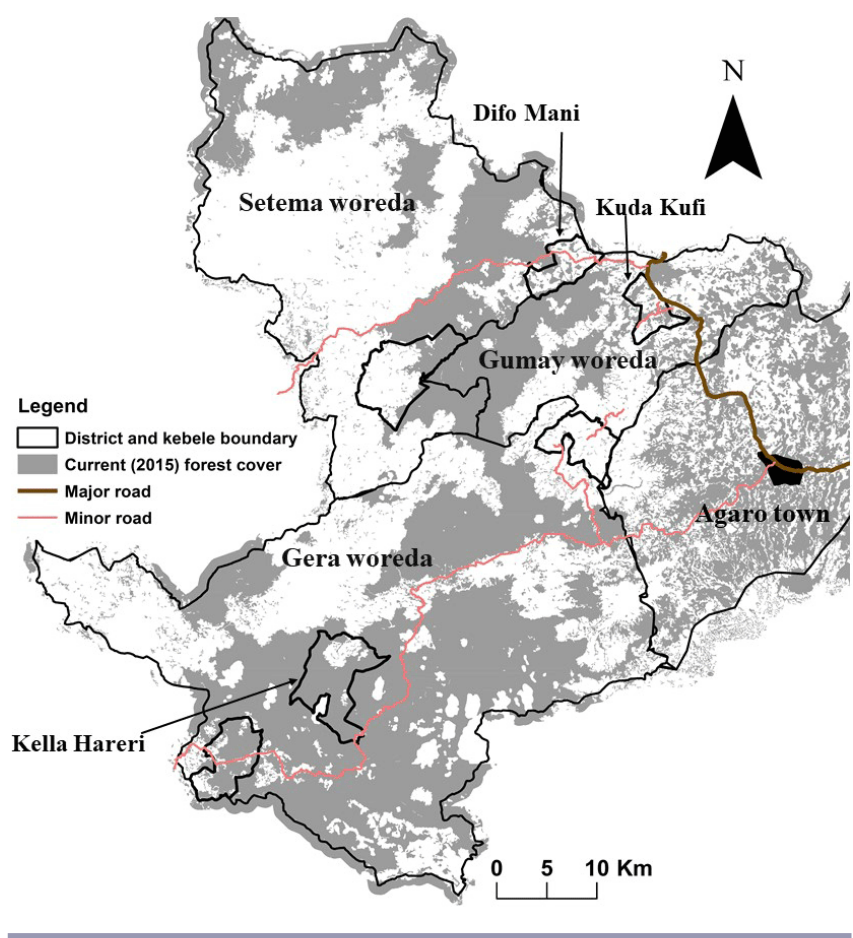

Study design and analysis

As a first step, we identified stakeholders concerned with issues around food security and biodiversity conservation in the study area (Table A1.1). These stakeholders included local people and their organizations, governmental and nongovernmental organizations, and civil society organizations. The identification of these stakeholders was based on a priori knowledge of the 
landscape, including an in-depth stakeholder analysis previously conducted (Jiren et al. 2018b). Based on this, we involved 35 stakeholder organizations, including representatives from the kebele, woreda, and zonal levels. These 35 stakeholders represented 29 different types of organizations. Some of the stakeholders were similar at the woreda and zonal levels, e.g., the Bureau of Agriculture and Natural Resources has representations at both woreda and zonal levels. We sought to have a high diversity in participating. First, we included stakeholders from the local people as well as stakeholder organizations operating at the three administration levels: kebele, woreda, and the zone (Table A1.1). Second, we selected stakeholders from government organizations, nongovernmental organizations, and community organizations. That said, in the study area, government organizations are dominant and there are only very few nongovernmental and community-based organizations (see also Jiren et al. 2018b). Third, we considered stakeholders from multiple sectors, including biodiversity and food security. Stakeholders represented different aspects of food security such as production, accessibility, finance and economy, marketing, and utilization; similarly, stakeholders from the biodiversity sector represented aspects such as forest and wildlife conservation. Cross-sectoral organizations such as the Women's and Children's Affairs Office, education institutions (including Jimma University), and health officers were also involved. At the community level, local people and their social organizations such as groups of women, men, community leaders, religious leaders (both Muslims and Orthodox Christians), community cooperatives, health professionals, and elementary school teachers took part in the study (Table A1.1). Specifically, workshop participants included different segments of the society, namely the youth and elders, men and women, and officials and bureaucrats, academicians and researchers, and also less educated people in the landscape.

Following the identification of stakeholders, we conducted a first round of eight separate participatory workshops. We maintained diversity of stakeholders by selecting stakeholders from different sectors including food security, biodiversity, social sector stakeholders, local people, and their organizations. Three stakeholder workshops were implemented at the kebele level, three at the level of each woreda, and two stakeholder workshops were held at the zonal level. These initial workshops were conducted from December 2014 to January 2015 and were used to identify the main social-ecological changes over the past 20 years related to food security and biodiversity conservation. Identifying these past changes served to identify key drivers and dynamics of the social-ecological system, construct system dynamics in the form of causal loop diagrams, and was the basis for the identification of future changes in the landscape. After identification of past changes, we collected information on the changes expected to happen in the next 20 years related to food security and biodiversity conservation. Here, we asked workshops participants to list the types of changes they expect to happen in the future, both changes that follow from the past trends, and new changes expected to happen based on plausible social-ecological dynamics around food security and biodiversity conservation in the coming 20 years. We decided on a 20 -year time frame, rather than 30 or 50 years because changes in socioeconomic and political conditions are rapid. When convening of the workshops, in the second and third rounds of the workshops, we provided refreshment snacks and a very modest payment to recognize participants' time contribution. However, given the small amounts involved, it was highly unlikely that the payment was the reason why participants participated in the workshops.

After identifying key social-ecological variables and changes, we asked participants to identify important drivers of changes related to food security and biodiversity conservation and assess their certainty and controllability (for methodological details, see Daconto and Sherpa 2010). Drivers of changes were conceptualized as driving forces that changed the socialecological dynamics related to food security and biodiversity conservation. We asked the workshop participants to classify drivers of changes as certain or uncertain, and controllable and uncontrollable at the local level. This exercise yielded "certain changes" indicating those changes that were expected by the participant stakeholders to happen certainly, and "uncertain changes," which participant stakeholders marked as changes that might or might not happen, or changes where the direction of change was perceived as not clearly known by the stakeholders. Thus, a given driver of change was considered uncertain when the workshop participants were uncertain how it might develop or unfold over the coming 20 years. For instance, land use strategies were considered uncertain because participants in all workshops indicated that it was uncertain whether commercial crops or food crops would dominate the landscape in the future. Similarly, "controllable changes" were considered to be under the influence of local stakeholders, whereas "uncontrollable changes" were those over which stakeholders in the study area had no control. For instance, the coffee market was considered uncontrollable because stakeholders in the study area do not control the price of coffee, which is determined by global market forces. In all these exercises, the system boundaries were set spatially to the study area; temporally to the time frame of 20 years in the past to 20 years in the future; and thematically to all social, economic, and ecological dynamics that may influence food security or biodiversity conservation.

Finally, participants were asked to identify causal relationships between the drivers as well as their influence on food security and biodiversity conservation. This led to the development of causal effect chains and draft causal loop diagrams. The collected draft causal loop diagrams and other data from the eight separate initial stakeholder workshops were then analyzed and integrated by a core team of authors at Leuphana University. We decided to integrate the multiple causal loop diagrams and develop draft scenarios within the author team because the stakeholders' diversity and geographical area covered were large; and we felt that certain voices would be more effectively represented this way than if we had conducted a smaller number of larger workshops. That is, the eight initial workshops served to elicit a breadth of perspectives, where all stakeholders would feel heard. We then provided opportunities for all stakeholders to refine or even substantially change the draft scenarios we generated in the subsequent stakeholder workshop.

In terms of specific steps, we merged similar variables identified in the eight workshops, both past and expected drivers of changes, and derived a single integrative causal loop diagram. For instance, "modernized and high external input farming" was used to group variables related to mechanization, improved seed, and fertilizer 
and agro-chemical use that were mentioned in the eight initial workshops. This diagram retained dynamics generally agreed upon but removed internally inconsistent or contradictory dynamics. Importantly, as stated above, stakeholders were subsequently given an opportunity to comment on the integrative causal loop diagram. In addition, we generated a thematic list of drivers, i.e., social, demographic, economic, environmental, technological, and policy-related, and arranged these according to the level of certainty and controllability (see above, as well as Daconto and Sherpa 2010).

The resulting causal loop diagram captured the most consistently and repeatedly reported variables and relationships as elicited in the individual workshops. Here, the key point was not on applying a rigid process to pick the "right" variables, but rather, we identified key themes and dynamics that characterized socialecological change in the landscape, and presented those back to stakeholders to check with them if we had heard them well. Thus, we first simplified the drivers through merging some of the original 174 variables identified, or leaving out highly idiosyncratic ones. Then, for the sake of clarity, we only presented 32 frequently mentioned variables across the eight workshops in the causal loop diagram. Notably, a causal loop diagram with 32 variables is still highly complex. Based on the final causal loop diagram, we identified key reinforcing and balancing feedbacks.

The process of scenario development focused on a subset of the most consistently reported, i.e., repeatedly mentioned across the eight workshops, as well as the most uncertain drivers of changes, as identified by stakeholders. Broadly speaking, these critical uncertainties were related to land use strategies and agricultural production techniques. That means, how land is allocated between different land use strategies, i.e., land use for commercial crops versus land use for food crops productions, and associated agricultural techniques, i.e., intensive agricultural practices versus the agroecological and traditional agricultural techniques. The scenarios were developed following the critical uncertainties identified during the workshops in the study landscape. In additions, other drivers of change, e.g., climate change or population growth, identified in the workshops were also considered in the scenarios, in ways that were consistent with the overall narratives generated.

Through this, we developed four internally consistent narratives that plausibly reflected the future of southwestern Ethiopia. These scenarios were neither predictions of the future, nor did they span the full range of plausible (let alone possible) changes that may take place; rather, the scenarios were representative illustrations of different futures that may emerge in the region, including the extremes along the possible gradients of land use strategies (from cash crops to food crops) and agricultural techniques (agroecological to industrial). The narratives of each scenario indicated the dynamics leading to the scenario over the coming 20 years, internal characteristics including socioeconomic and ecological dynamics, as well as food security (food availability, access, utilization, and stability) and biodiversity (farmland and forest) outcomes.

After the development of these initial scenario narratives, in February 2018, we conducted six validation workshops with the same stakeholders previously involved. The only difference was that we held one joint validation workshop at the zonal level (instead of two separate workshops), and one joint workshop for the two nearby kebeles Kuda Kufi and Difo Mani (instead of two separate workshops). The validation workshops sought feedback on the causal dynamics identified, and sought to ensure the internal consistency of scenario storylines, their plausibility, and validity from the perspective of local stakeholders. Based on the feedback obtained from the participants, we refined the scenario narratives along with their defining characteristics or key features that made each scenario different from the others. Notably, relatively major changes were made to one draft scenario based on this feedback, whereas the other three scenarios required only minor modifications. Finally, one author $(\mathrm{JH})$ visualized features of each scenario through stylized paintings that depicted what the landscape might look like in 20 years.

Having generated a complete set of refined and validated scenarios, we conducted a third round of workshops in November 2018, specifically designed to generate impact, that is, to initiate discussions among a wide range of stakeholders about how to best approach the future, given the scenario exercise that had been completed. To this end, we organized a series of workshops at kebele and woreda levels, where we presented the scenarios and distributed posters and leaflets to initiate discussion among stakeholders. We also organized a two-day meeting at the zonal level where participants from local (woredas) and higher levels (zone, region, and federal), representing community, nongovernmental, governmental, and academic interests, participated. All stakeholders who had participated in the initial and validation workshops also participated in the third round of workshops. In all workshops and at the conference, stakeholders jointly discussed and deliberated on what each of the scenarios implies for the landscape, and discussed what would constitute a desired outcome in terms of integrating food security and biodiversity goals. For this, an open-access booklet (Fischer et al. 2018) was prepared and distributed to the stakeholders to also facilitate discussions beyond the workshops. For the woreda workshops and zonal conference, we prepared a feedback questionnaire for participants, asking them: (a) what they liked and did not like in the process of scenario development; (b) whether the scenario exercise assisted them to think about the future in different ways and if so, how; (c) whether they think that the outcome of the scenario planning process will facilitate further discussion among stakeholders about the future of the landscape. With this questionnaire we aimed at understanding the impact of scenario development for local stakeholders. We randomly distributed this questionnaire to 70 participants who all returned it. Data from this was transcribed and analyzed for its themes using NVivo software. All stakeholder workshops were conducted in the local language, Afaan Oromo, and were facilitated by the authors of this paper with the help of local guides.

\section{RESULTS}

\section{Drivers of change}

Past drivers of changes in the landscape were related to the social and demographic, economic, environmental, technological, and political and to governance (Table A1.4). Some of these drivers of changes were identified to characterize changes over the coming 20 years, some of them reported as certain, while others as uncertain (Table 1). Education, gender equality, and employment were perceived as certain changes that were 
Table 1. Drivers of change in the study landscape as reported by local stakeholders.

\begin{tabular}{|c|c|c|c|c|}
\hline \multirow[t]{2}{*}{ Type of driver } & \multicolumn{2}{|c|}{ Certain } & \multicolumn{2}{|r|}{ Uncertain } \\
\hline & Controllable & Uncontrollable & Controllable & Uncontrollable \\
\hline \multirow{5}{*}{$\begin{array}{l}\text { Social } \\
\text { Demographic }\end{array}$} & Education & & & Local living conditions \\
\hline & Gender equality & & & Food security \\
\hline & Drug addiction (khat use) & & & Religious extremism \\
\hline & & & & Social trust and tradition \\
\hline & $\begin{array}{l}\text { Reduced mothers' and children's } \\
\text { mortality }\end{array}$ & Population growth & & \\
\hline \multirow[t]{4}{*}{ Economic } & Employment & Coffee market & & Income \\
\hline & Coffee productivity & & & Equity \\
\hline & & & & Financial access \\
\hline & & & & Inequality \\
\hline \multirow[t]{7}{*}{ Environmental } & & & & Agricultural production techniques \\
\hline & & & & Land use strategies \\
\hline & & & & Forest condition \\
\hline & & & & Wildlife populations \\
\hline & & & & Climate change \\
\hline & & & & Farm biodiversity \\
\hline & & & & Food crop productivity \\
\hline \multirow[t]{3}{*}{ Technological } & Modernization & & & \\
\hline & Phone network & & & \\
\hline & Road network & & & \\
\hline \multirow[t]{2}{*}{ Governance and political } & Democracy & & & Land tenure \\
\hline & Participation in decision making & & & Social security and conflict \\
\hline
\end{tabular}

considered to improve, while other drivers such as drug addiction, through increased chewing of khat, were considered to worsen, but perceived as controllable by the stakeholders. In contrast, demographic changes, e.g., population, and economic changes, e.g., coffee market, were perceived as certain and beyond the control of stakeholders. The most important uncertain and uncontrollable changes spanned a wide range of topics including local living conditions, social trust and traditions, income, equity and equality, agricultural production techniques, land use strategies, forest condition, wildlife population, climate change, and land use rights (Table 1).

\section{Social-ecological dynamics}

Of the 174 drivers we included the 32 most frequently mentioned ones in a causal loop diagram. The diagram includes the most important links between the variables and with food security and biodiversity as perceived by the workshop participants (see full diagram in Fig. A1.1). Many variables in the causal loop diagram describe dynamics related to the main livelihood activity, i.e., smallholder farming. At the core of this stands a balancing feedback loop that describes the allocation of land for either food crops, e.g., maize, teff, and sorghum, or cash crop production, e.g., coffee, khat, and Eucalyptus. The balancing effect arises from the fact that farmland is finite.

Despite this, yields of both food and cash crops can increase with farm modernization through an increasing application of external inputs such as agrochemicals and inorganic fertilizers, which can lead to higher incomes, i.e., farm modernization $\rightarrow$ food crops yield and cash crops yield (Fig. A1.1). Increased income can on the one hand improve financial access to food and thus food security, but on the other hand needs to be reinvested into farming inputs, i.e., income $\rightarrow$ modernized farming $\rightarrow$ food crops yield and cash crops yield (Fig. A1.1). In this way, modernized farming constitutes a reinforcing feedback mechanism that is further facilitated through improvements in infrastructure such as market access, farmer training, and cooperative functions, i.e., cooperative functions $\rightarrow$ farmers training $\rightarrow$ modernized farming $\rightarrow$ food crops yield and cash crops yield (Fig. A1.1). However, this feedback mechanism also leads to biodiversity loss and environmental degradation as well as losses of traditions, knowledge, and practices, i.e., modernized farming $\rightarrow$ - natural capital farmland and natural capital forest; modernized farming $\rightarrow^{-}$traditional management and life (Fig. A1.1). Such societal change, in turn, is not only driven by a transformation of the farming system, but also by demographic processes. Human population growth, which in turn could be reduced by family planning and women's participation, was a key factor (women participation $\rightarrow$ family planning $\rightarrow^{-}$population growth and density). According to our simplified causal loop diagram, increases in population size and density lead to land scarcity, which leads to conflict over resources, emigration, and increasingly prevents farmers from traditional management of resources, consequently constraining sustainable and sufficient food crop production, i.e., population growth and density $\rightarrow$ land scarcity and conflict $\rightarrow$ migration and urbanization $\rightarrow{ }^{-}$traditional management and life $\rightarrow$ food crops yield and cash crops yield (see Fig. A1.1). Land scarcity and the increasing need to provide more food lead to the expansion of farmland into forests or traditional grazing land, and thus ultimately to the loss of biodiversity and natural capital.

Although local traditions and informal social institutions could benefit food security in general, for example, by limiting wild animal crop-raiding, increasing conflicts and pressures were seen to cause the loss of traditions and informal arrangements, i.e., land scarcity and conflict $\rightarrow$ - traditional management and life $\rightarrow$ food crops yield and cash crops yield (Fig. A1.1, Table A1.3). Such informal institutions, however, facilitate participatory resource governance, which was perceived to enhance both food 
security and biodiversity through collective action, social learning, and the empowerment of disadvantaged groups such as women and poor people, i.e., traditional management and life $\rightarrow$ participatory resource governance $\rightarrow$ natural capital farmland and natural capital forest $\rightarrow$ food crops yield and cash crops yield (Fig. A1.1, Table A1.3).

\section{The four scenarios}

Based on the key uncertainties (Table 1) and social-ecological system dynamics (Fig. A1.1) we developed four plausible scenarios for the study landscape. The scenarios were related to land use strategies and agricultural production techniques, and cover a gradient from a stronger focus on producing cash crops to a stronger focus on producing food crops in the area. The four scenarios were termed "gain over grain: local cash crops," "mining green gold: coffee investors," "coffee and conservation: a biosphere reserve," and "food first: intensive farming and forest protection." We present short summaries of the scenario narratives together with visualizations of current and future landscape conditions (Figs. 2, 3). Subsequently, we summarize the scenario outcomes in terms of food security and biodiversity conservation. The full scenario narratives are presented in the supplementary online text (Appendix 1).

Fig. 2. Landscape view at present and in the four scenarios. The current landscape consists of a mosaic of food crops, cash crops, pasture, forest, and settlements. "Gain over grain" consists of a landscape covered by different cash crops, while the landscape in "mining green gold" is dominated by intensive coffee plantations. The "coffee and conservation" scenario is similar to the current landscape in that different crops, trees, and settlements coexist. The "food first" scenario consists of a landscape where intensively produced food crops cover farmland, while forestland is spared and strictly protected from human access.

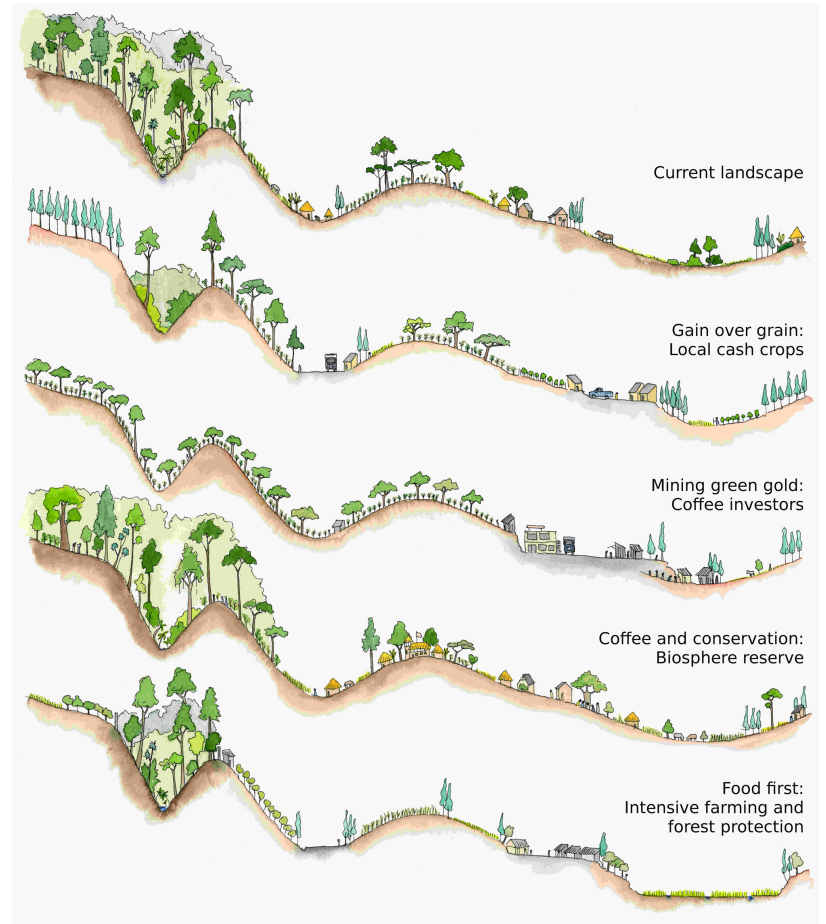

Fig. 3. Visual representation of the key features of the four scenarios in terms of landscape features and composition in a village. The "gain over grain" scenario is characterized by a landscape consisting of coffee, khat, and eucalyptus, with settlement areas providing local markets for these cash crops. Infrastructure such as roads to the investment area is improved, and the landscape harbors coffee plantations in the "mining green gold" scenario. Traditional lifestyles where settlements are interspersed with forest and diverse crops characterize the "coffee and conservation" scenario. Areas of consolidated and intensively used farmland, fruit tree plantation, and intensive cattle raising characterize the "food first" scenario.

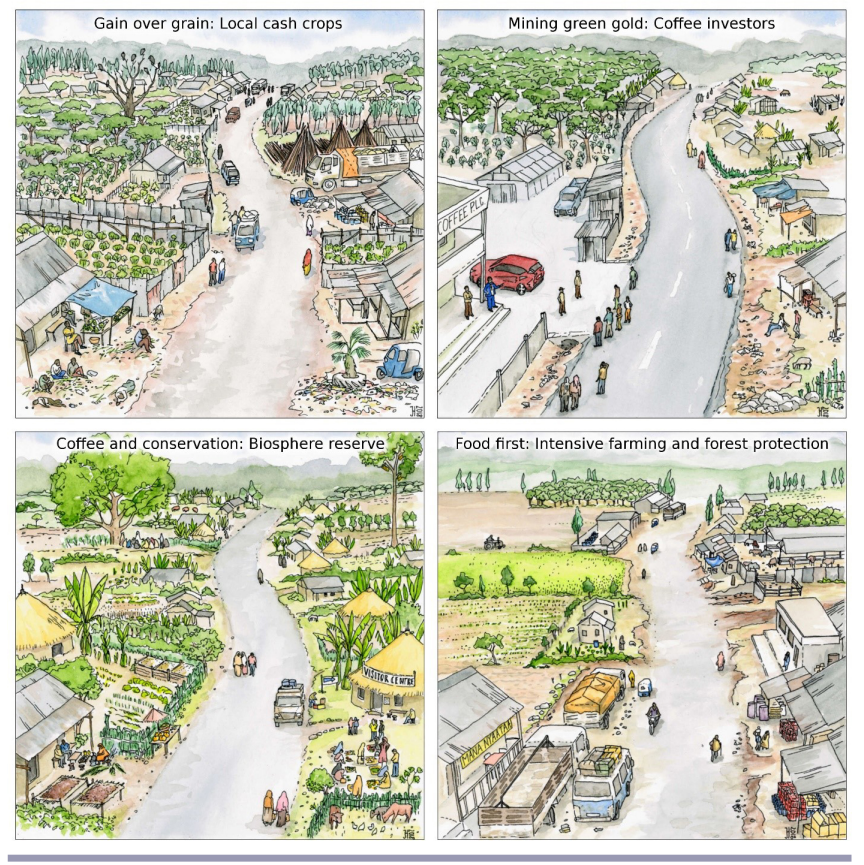

Gain over grain: local cash crops

The Ethiopian government has prioritized farmer specialization and commercialization to boost development. As a result, southwestern Ethiopian farmers have abandoned traditional food cropping and focus on cash crops for which biophysical conditions are suitable: coffee, khat, and fast-growing trees including Eucalyptus. This scenario is driven by a reinforcing feedback loop around increasing smallholders' income through increasing efficiency in the commercial production of crops through modernized and high external input farming. The landscape now consists of intensively managed coffee forests interspersed with khat and tree plantations, while the production of food crops is limited (Figs. 2, 3). Although the income the farmers producing commercial crops increases, food security and especially dietary diversity for many rural people remains low. Farmland biodiversity is dramatically reduced because of simplified habitats and intensive management. Forest biodiversity is also reduced because of intensive coffee management, but forest wildlife still persists. Wildlife raids of food crops heavily impact farmers. Living standards are high for some, but less wealthy farmers and landless people have been marginalized and are worse off now 
than in the past. Social costs are high: commercialization through cash crops has reduced traditional cooperative management, khat consumption involves health risks, and mistrust is high within the community.

\section{Mining green gold: coffee investors}

International coffee markets and prices have led the government to prioritize southwestern Ethiopia for export coffee production. Large-scale coffee investors have been given land, because smallholder farmers lack the capacities to produce for export. This scenario is driven by a reinforcing feedback loop around increasing national income through increasing efficiency in the production of commercial coffee crops through intensification and specialization - modernized and high external input farming - of coffee production by large-scale agricultural investment by national or foreign coffee investors. The landscape now consists of monoculture, high-yield coffee plantations, and relatively little food is produced (Figs. 2, 3). Both farmland and forest biodiversity have declined considerably because of monocropping and intensive management. Native coffee varieties have disappeared because of the influx of high-yield varieties. Farmers have lost land to investors and many received inadequate compensation. Promises by investors of job opportunities and improved public infrastructure have fallen short of local expectations. Poverty, food insecurity, land scarcity, and conflicts between coffee investors and local communities have resulted in the emigration of locals. Traditional farming and culture have been lost almost entirely.

\section{Coffee and conservation: a biosphere reserve}

Conventional agriculture in Ethiopia has failed because of land degradation, and has been replaced by sustainable approaches. Global interest in sustainably grown coffee is increasing. A biosphere reserve has been established that combines sustainable agriculture, eco-coffee production, and tourism opportunities. This scenario is driven by a reinforcing feedback loop around improving farmland and forest natural capital through agroecological production techniques including maintaining agrobiodiversity and investment in participatory resource governance, which enhances long-term sustainability of the landscape. The landscape around a core area of sustainably managed forest consists of a mosaic of diversified farmland and forests (Figs. 2, 3). Farmland biodiversity has recovered because of varied habitats and sustainable agricultural practices. Forests and wildlife are managed by the community, and forest biodiversity is relatively high. All people including the poor produce their own food as well as products for export, supported by a revival of traditional cooperative farming arrangements. Economic growth is slow but steady and equitable, and living conditions slowly improve. Household resilience is high because of strong social capital, diversified farming, and new income opportunities from tourism.

\section{Food first: intensive farming and forest protection}

The government has pushed for commercialized food production in southwestern Ethiopia and has protected existing forests to meet its global commitments. Climate change has made coffee production unviable in the southwest, and food production elsewhere in the country is also failing. Large amounts of food (primarily for sale within Ethiopia) are now produced in the southwest through intensive, large-scale agriculture. This scenario is driven by a reinforcing feedback loop around increasing household income and food self-sufficiency through increasing efficient production of food crops by modernized and high external input farming. The landscape consists largely of fruit and vegetable plots, maize and teff fields in the wetlands, and pastures for beef fattening (Figs. 2, 3). Remaining forest areas are strictly protected and not accessible to locals. Farmland biodiversity has plummeted because of intensive management, but forest biodiversity remains high. Some farmers are better off, but poverty is widespread among those who lost land and could not capitalize on new agricultural opportunities; their food security is low. Community resilience is limited because of fluctuations in climate and markets, and many poor people emigrate to urban areas.

\section{Food security and biodiversity outcomes in the scenarios}

Each scenario generated specific outcomes for food security, biodiversity, and their integration. For food security, the scenarios differed with regard to availability of food, financial accessibility, and dietary diversity. The food first scenario provided the best outcome in terms of food availability and financial capacity because local people produce food crops for consumption and market surplus to generate income. In contrast, the mining green gold scenario provided the lowest food availability, and local people's financial capacity to access food was also low because economic returns from coffee primarily benefitted external investors (Table 2). The gain over grain scenario increased smallholders' financial incomes. However, the focus on commercial crop production limited food crop availability in the landscape. Finally, the coffee and conservation scenario enabled food availability and dietary diversity because in this scenario, local people produced diverse food crops for their own consumption; and food accessibility was most equitable in this scenario (Table 2).

For biodiversity conservation, the coffee and conservation scenario provided the best outcome, because the biosphere reserve provided habitat for forest species through a strictly protected core area, as well as habitat for farmland species in a heterogeneous and ecologically managed agricultural landscape. In contrast, agricultural intensification through the application of agrochemicals and artificial fertilizers, improved seeds, and landscape homogenization resulted in the loss of farmland biodiversity in the other three scenarios. Forest biodiversity was partially maintained in the food first scenario because of the strict protection of forest remnants. Intensified coffee management practices caused the loss both of farmland and forest biodiversity in the remaining two scenarios (Table 2).

The mining green gold scenario threatened local people's food security as well as biodiversity conservation, and thus provided a lose-lose outcome for food and biodiversity. The food first scenario, in contrast, provided some benefits for both food and (forest) biodiversity, but the biodiversity benefits were partly offset by intensive land use practices outside the protected areas. Through the implementation of land use zoning, the coffee and conservation scenario provided a win-win situation where both food security and biodiversity conservation benefitted. Finally, the gain over grain scenario benefitted food security through increasing the incomes of smallholder producers, while intensive production on the farmland and within the forest threatened biodiversity conservation (Table 2). 
Table 2. Outcomes of scenarios: Individual outcomes and integration of food security and biodiversity conservation in each of the scenarios. A dagger $\left(^{\dagger}\right)$ indicates that those households that can afford to produce cash and food crops for markets obtain high financial incomes, whereas landless and poor people get poorer in terms of financial income under these scenarios.

\begin{tabular}{|c|c|c|c|c|c|}
\hline Scenarios & & $\begin{array}{l}\text { Gain over grain: local } \\
\text { cash crops }\end{array}$ & $\begin{array}{l}\text { Mining green gold: coffee } \\
\text { investors }\end{array}$ & $\begin{array}{l}\text { Coffee and conservation: } \\
\text { a biosphere reserve }\end{array}$ & $\begin{array}{l}\text { Food first: intensive farming } \\
\text { and forest protection }\end{array}$ \\
\hline \multicolumn{6}{|c|}{$\begin{array}{l}\text { Key features and } \\
\text { outcomes }\end{array}$} \\
\hline \multirow[t]{4}{*}{ Food security } & Food availability & Medium to high & Low & Self-Sufficient & High \\
\hline & $\begin{array}{l}\text { Access and financial } \\
\text { capacity of } \\
\text { households }\end{array}$ & Low to high $^{\dagger}$ & Low & Moderate to high & Low to high $^{\dagger}$ \\
\hline & Dietary diversity & Low & Low & High & Low \\
\hline & $\begin{array}{l}\text { source and type of } \\
\text { food }\end{array}$ & Purchased food & Purchased food or food aid & $\begin{array}{l}\text { Local production and } \\
\text { food sovereignty }\end{array}$ & Processed food from markets \\
\hline \multirow{2}{*}{ Biodiversity } & Farmland & Decline & Decline & Maintained & Decline \\
\hline & Forest & Decline & $\begin{array}{l}\text { Decline (incl. local coffee } \\
\text { varieties) }\end{array}$ & Maintained & Partially maintained \\
\hline $\begin{array}{l}\text { Integration } \\
\text { approaches }\end{array}$ & & $\begin{array}{l}\text { Some unintentional } \\
\text { integration through } \\
\text { agroforestry }\end{array}$ & No integration & $\begin{array}{l}\text { Multifunctional mosaic } \\
\text { landscape }\end{array}$ & Land sparing approach \\
\hline
\end{tabular}

\section{Stakeholder perceptions of the scenario development process} All stakeholders positively evaluated the overall scenario development process. Six aspects of the scenario development process were considered most important by the respondents. First, the majority of participants at the woreda and zonal levels $(88 \%)$ mentioned that they liked the overall organization including the timing and facilitation of workshops and conferences, and the distribution of outreach material. For example, one woreda respondent indicated, "The distributed scenario materials will help us to continually remind ourselves and guide our actions and services accordingly." Second, the majority of respondents $(87 \%)$ liked that the process of scenario development was inclusive toward stakeholders from multiple sectors. Third, $84 \%$ of respondents liked that the scenario development process provided new perspectives and helped them to be prepared for the future. Here, one respondent stated, "Every year we develop a future plan in the form of annual and midterm five year plan. However, this scenario process showed us a holistic and broader picture of the future of our landscape." Fourth, some participants (60\%) liked that the scenario development was a joint undertaking and not as extractive as conventional academic research. Fifth, approximately half of the respondents $(51 \%)$ valued the time allocated to group discussions where stakeholders deliberated on the drivers, scenarios, pros and cons of the scenarios and reported back to the entire group afterward. Sixth, some stakeholders $(42 \%)$ appreciated that the zonal conference brought together stakeholders from the policy level (federal, regional, zonal) and implementation level (woreda).

In contrast, stakeholders mentioned two issues that they disliked, or that could be improved in the future. First, 33\% of respondents indicated that the scenario development process should not end at this stage, but that there was a need for continuing to engage with stakeholders and plan which steps toward a desirable future should be taken. Second, $19 \%$ of respondents indicated that the number of kebele participants, including local farmers, should increase in the future.

Regarding long-term impact, stakeholders replied that the scenario planning process would help them to think about the future of their landscape and the need of integrating food production and biodiversity conservation $(67 \%)$ and that it would facilitate future discussion and cooperation (56\%). However, 19\% of respondents did not believe the process could bring together stakeholders in the future, because, to foster stakeholders' joint work, a further step of discussing the specific implications and actions would be required.

\section{DISCUSSION}

Participatory scenario planning can serve as a tool to explore development pathways of complex systems and thus help to inform planning for sustainable development (Flynn et al. 2018). Here, we implemented such a process and developed a set of future exploratory scenarios for southwestern Ethiopia, an area that is characterized by smallholder farming, rapid population growth, and fast environmental change. In our study we identified important social-ecological dynamics that influence changes in the study landscape, and these dynamics were related to the various social, economic, environmental, technological, and governance and political drivers. We also found that the main critical uncertainty was related to future land use strategies and agricultural techniques, that is, how land is allocated among different crops and stakeholders. Understanding of the dynamics and critical uncertainties produced the four plausible future scenarios, gain over grain, mining green gold, coffee and conservation, and food first. These future scenarios evolve under different dynamics (see Appendix 1), and also differ with respect to their food and biodiversity outcomes (Table A1.2). The process of scenario planning provided a structured process for stakeholders to engage with the long-term future, to explore the effects of uncontrollable and uncertain changes, and to elicit how certain actors and policies or governance settings may influence future change (Daconto and Sherpa 2010). However, because participatory scenario planning is primarily a place-based visioning exercise, our discussion primarily relates to the socialecological dynamics of the southwest Ethiopian landscape, with relatively less emphasis on potentially uncertain higher level dynamics. 


\section{Social-ecological dynamics}

Disentangling the dynamics of social-ecological systems is a prerequisite to identify drivers of change and thus to successfully manoeuvre future developments (Meadows 1999). The dynamics of social-ecological systems are often characterized by a small number of feedback mechanisms that determine sustainability outcomes (Hersperger et al. 2011). Here, we discuss the key feedbacks observed in the different scenarios.

Most importantly, three of the four scenarios, i.e., gain over grain, mining green gold, and food first, were driven by a reinforcing feedback loop around increasing efficiency in agricultural production through intensification, specialization, and commercialization. In general, this feedback mechanism can lead to increasing profits, which can benefit food security, but which also need to be reinvested into further inputs such as agrochemicals, machinery, or seeds. Current policies of the Ethiopian government strongly support this dynamic because it is seen as one of the key pathways to rural development (MOFED 2010, Federal Democratic Republic of Ethiopia 2011). At its core this strategy follows the logic of the green revolution, which is currently guiding development of the farming sector in order to boost financial income as a means to achieving food security all over Africa (NEPAD 2003, Shiva 2011, AfDB 2014).

The differences between the three scenarios involving such a green revolution type of modernization show that this feedback mechanism can lead to different social-ecological outcomes depending on crop choices and the specific actor and governance constellations. For instance, as indicated in our findings, although the feedback mechanisms of the mining green gold and food first scenarios were built around modernization of agriculture, their outcome in terms of food security varies because the former chose commercial crops whereas the latter focused on food crops. Similarly, because of differences in actors between gain over grain and mining green gold, the outcomes and beneficiaries vary between these scenarios. This finding thus shows the range of possible development options available and demonstrates the uncertainties of future developments, even when following a green revolution development logic. Although market mechanisms are key in all of these instances, additional policy settings and differing emphasis on certain actors steer the system into different directions. This is most obvious in the mining green gold scenario, where poor land tenure rights, prioritization of national revenues, and the influence of external agricultural investors leads to a type of land grabbing, which would largely exclude local people from the financial benefits of development. Such development has been reported for other parts of Ethiopia where land grabbing by private agricultural investors has led to a displacement of smallholders from their farmland (Rahmato 2011), and, to a limited extent, in Jimma Zone (Ango 2018).

Notably, the strong reinforcing feedback mechanism built into a green revolution type pathway could have a series of negative effects on some social and ecological variables. For instance, the scenario narratives (see Appendix 1) suggest that an agricultural intensification pathway might create social injustices, this is, evident in the mining green gold scenario, but also in the other two cases, which also see rising inequalities and the loss of traditions and local knowledge (also see the causal loop diagram in Fig. A1.1, where modernizing agriculture negatively influences traditional management and life). Second, we found that land use intensification would likely lead to the decline of biodiversity both in farmland and in the forest, i.e., modernized and high external input can be expected to negatively influence both farmland and forest natural capital (Fig. A1.1). Biodiversity loss is caused directly through habitat loss because of expansion and consolidation of farmland, but also through increased application of agrochemicals. Consistent with our findings, this side-effect of modernized conventional farming has been considered as a strong contributor to global biodiversity loss (Grau et al. 2013, Gonthier et al. 2014). Although biodiversity loss is partly being counteracted through strict protection of some of the remaining forests in the food first scenario, biodiversity benefits may be minimal or absent in practice because increased agricultural profitability could encourage further agricultural expansion, a problem known as an example of the "Jevons Paradox" (Matson and Vitousek 2006, Desquilbet et al. 2017).

In contrast to these three scenarios, the coffee and conservation scenario is driven by a very different dynamic. It is based on the reinforcing mechanism of agroecological production methods increasing natural capital, which in turn, provides diverse harvests, a wide range of ecosystem services, and enhances the long-term sustainability of the landscape. The causal loop diagram describes this dynamic by the links between crop diversity and participatory resource governance with farmland and forest natural capital, which in turn increases both food crop yield and cash crop yield (Fig. A1.1). This dynamic is based on a strong emphasis on local agency and participation, and it integrates different land use strategies within a multifunctional landscape. Besides smallholder farmers, this scenario also includes nongovernmental actors (Appendix 1); the governance mechanisms thus are collaborative, involving multiple sectors and levels (Table A1.2). Overall, this scenario strongly resonates with the agroecology paradigm (Altieri et al. 2012, Kremen 2015). This approach is also represented by many other farming systems in the world such as the Satoyama landscapes (https://satoyamainitiative.org/about/). Importantly, implementing this development pathway would not necessarily require radical changes in southwestern Ethiopia, but resonates with the existing culture and traditions of small-scale farming and preferences of local stakeholders (Jiren et al. 2018b). However, key challenges could be the navigation of power devolution (Ayana et al. 2013), and the implementation of participatory management and capacity building (Ayana et al. 2013, Jiren et al. 2018b).

\section{Trade-offs and synergies for food security and biodiversity conservation}

Identifying synergies for food security and biodiversity conservation is a key challenge for research and policy (Brussaard et al. 2010, Fischer et al. 2017). We discuss the outcomes of the different scenarios and how these relate to each other. A clear trade-off was apparent in the three intensification scenarios, most strongly in the gain over grain and mining green gold scenarios. Here, increasing agricultural production leads to an overall increase in food security, but at the cost of biodiversity in farmland and forest, a typical trade-off that has been described for intensively used landscapes around the world (Fischer et al. 2017). According to our simplified causal loop diagram, modernized farming increases food security, i.e., boosting the yields of food crops and cash crops, while at the same time causing degradation 
of farmland and forest (Fig. A1.1). Elsewhere, too, a strong emphasis on industrial farming for economic development has been shown not only to affect biodiversity (Cunneyworth 2001, Holt-Giménez and Altieri 2013, Konstantinidis 2018), but also leads to a loss of resilience to climatic and market shocks (Koohafkan et al. 2012, Fischer et al. 2017).

Although in the short term, intensification and specialization practices could increase income through national and international market integration, they are also associated with risks of crop losses and market failure, which may particularly threaten the future of smallholder farmers (Pender and Dawit 2007, Gebreselassie and Sharp 2007). Importantly, it is not only the increased susceptibility to shocks that would be unevenly distributed, but also the actual economic benefits and corresponding gains in food security. Intensification, commercialization, and specialization could benefit either richer locals or external investors because the majority of poor smallholder farmers would lack the capacity to intensify production and integrate into both domestic and global markets (Jiren et al. 2020). Research elsewhere, for instance, in other parts of Ethiopia (Horne et al. 2011, Rahmato 2011), in other subSaharan African countries (Cotula et al. 2009), or in South American and Southeast Asian countries (Zoomers 2010, Visser and Spoor 2011), has indicated that few capable actors benefit from market integration whereas often, the majority of poor smallholders may suffer further deprivation.

A clear balance between food security and biodiversity conservation can only be identified within the coffee and conservation scenario, in which people and biodiversity would both benefit from the proactive management of social-ecological interactions (Morrison and FitzGibbon 2014, Holt-Giménez and Altieri 2013, Kerr et al. 2016). As an indication of trade-offs, although this scenario would lack the rapid economic development that is inherent to the other scenarios, it would provide a system that is more resilient to environmental and economic shocks, thereby providing a more sustainable long-term perspective for the area.

This balance between food security and biodiversity conservation is grounded not only in diversification, agroecological techniques, and participatory resource governance (Fig. A1.1), but also in clear acknowledgment of the link between food security and social justice through the emphasis on local knowledge and institutions (traditional management and life; Fig. A1.1). This link is consistent with findings from elsewhere. For example, in a study in Tanzania, Mbunda (2017) attributed food insecurity primarily to a system guided by a capitalist policy narrative, emphasizing the necessity of refocusing on a system that nurtures local principles and practices of agroecology. Also, when comparing different cases of a win-win scenario in other systems, some common features are similar to those identified here. Often, win-win scenarios build on empowering smallholder farmers (Holt-Giménez and Altieri 2013, Fischer et al. 2017), focus on agroecological practices and diversified farming (Holt-Giménez and Altieri 2013, Kerr et al. 2016), emphasize adaptive governance of interdependent social-ecological systems (Morrison and FitzGibbon 2014), value local knowledge, culture, and traditions, ensure smallholder participation both in production and conservation activities (Altieri et al. 2012, Bailey and Buck 2016,
Glamann et al. 2017), and promote enhanced resilience capacity of smallholders (Tengö and Belfrage 2004, Bacon et al. 2012).

\section{IMPLICATIONS}

Global discussions are polarized as to whether economic gains (e.g., efficiency in production, trade, and profit maximization) or social-ecological system considerations (e.g., food sovereignty and agroecological production systems) are better suited to integrating food security and biodiversity conservation (McKeon 2014). In this study, a sustainable balance was identified for only one of the scenarios. Prioritizing desirable future outcomes is a key requirement to developing and implementing appropriate strategies and policy options (Henrichs et al. 2010). Importantly for this, development trajectories are strongly influenced by specific actor constellations and governance mechanisms (Adger et al. 2005). Our study shows that not only the national and zonal policies and their implementation, but also local actors will shape the future of southwestern Ethiopia. Thus, a sustainable transformation of Ethiopian agriculture, such as described by the coffee and conservation scenario, would benefit from an empowerment of local communities, more coordinated governance in the biodiversity sector, and stronger involvement of environmental NGOs (Järnberg et al. 2018). Such future development would help to yield sustainable outcomes because it would benefit a majority of the community including its most disadvantaged members while also maintaining biodiversity. To realize such improvements, a governance system needs to be put in place that promotes multistakeholder participation and interactions across multiple scales, sectors, and institutions, and explicitly supports land use strategies and approaches that encourage agroecological production. Such changes to the status quo would be consistent with the recommendations generally derived from work on adaptive comanagement and resilience (Olsson et al. 2007, Plummer et al. 2013, Biggs et al. 2015).

Because scenario planning is a place-based visioning exercise, our study primarily relates to the social-ecological dynamics of southwestern Ethiopia. Similarly, although this study aimed to explore longer term social-ecological changes, it did not look at the dynamics beyond the time frame of the study. Most importantly, this includes the dynamics of human population growth, which most likely will be ongoing for many decades. Population growth is one of the most important drivers of change not only in our study area but many other parts of sub-Saharan Africa (UN 2015b). We incorporated some demographic aspects in our study within a 20-year time frame, e.g., emigration to towns and the need for strengthening family planning. Within the time frame of our study, however, the negative effects of unhindered population growth and possible migration remained somewhat hidden. Especially when looking beyond a 20 -year horizon, increased attention to the use of family planning and female empowerment, for example, through education, become extremely important.

\section{CONCLUSION}

Through iteratively engaging stakeholders from different sectors and governance levels in identifying important social-ecological dynamics and critical uncertainties, our study produced narratives of four plausible future trajectories, with different outcomes for food security and biodiversity conservation for southwestern Ethiopia. The four plausible trajectories discussed 
differ in the underlying dynamics that lead to the scenarios, along a gradient of a cash crop dominated landscape to a food crop dominated landscape. The four scenarios also differ in their system properties, such as land use strategies, actor constellations and governance mechanisms, as well as in the feedback mechanisms that drive the dynamics of a given scenario. Our discussion suggests that the most plausible means to integrate food security and biodiversity conservation in southwestern Ethiopia is to pursue a development direction that reflects local priorities and preferences, and includes the establishment of a governance system that ensures participation of a diversity of stakeholders. The trajectories identified in our case study may in fact be archetypical, that is, they may apply in similar ways to many other landscapes worldwide. Finally, transdisciplinary approaches such as participatory scenario planning are powerful to empower local people and promote mutual learning, enable stakeholders to proactively think about and navigate alternative futures, generate new knowledge, and initiate collective action to achieve a desired and sustainable future.

Responses to this article can be read online at: http://www.ecologyandsociety.org/issues/responses. php/11681

\section{Acknowledgments:}

The study was funded through a Consolidator Grant by the European Research Council (ERC) to Joern Fischer. We thank all local stakeholders who were involved in the scenario planning workshops at different stages. Special thanks go to Dadi Feyisa Damu and Birhanu Bekele Negash for facilitating group meetings in the study area. We would also like to thank our colleagues Girma Shumi Dugo, Patrícia Rodrigues, Aisa Manlosa, Abebe Tufa, and Lennard Thale-Bombien for their valuable insights and support. We thank the Governments of Ethiopia and Oromia for granting us the relevant permits.

\section{LITERATURE CITED}

Adger, W. N., T. P. Hughes, C. Folke, S. R. Carpenter, J. Rockström. 2005. Social-ecological resilience to coastal disasters. Science 309:1036-1039. https://doi.org/10.1126/science.1112122

Aerts, R., L. Geeraert, G. Berecha, K. Hundera, B. Muys, H. De Kort, and O. Honnay. 2017. Conserving wild Arabica coffee: emerging threats and opportunities. Agriculture, Ecosystems and Environment 237:75-79. http://dx.doi.org/10.1016/j.agee.2016.12.023

Africa Development Bank (AfDB). 2014. Grain fish money. Financing Africa's Green and Blue revolutions. Africa progress report. Africa Progress Panel, Geneva, Switzerland. [online] URL: https://www.afdb.org/fileadmin/uploads/afdb/Documents/ Project-and-Operations/Africa Progress Report 2014.PDF

Altieri, M. A., F. R. Funes-Monzote, and P. Petersen. 2012. Agroecologically efficient agricultural systems for smallholder farmers: contributions to food sovereignty. Agronomy for Sustainable Development 32:1-13. http://doi.org/10.1007/ $\underline{\text { s13593-011-0065-6 }}$

Ango, T. G. 2018. "Medium-scale" forestland grabbing in the southwestern Highlands of Ethiopia: impacts on local livelihoods and forest conservation. Land 7(1):24. https://doi.org/10.3390/ land 7010024

Ayana, A., B. Arts, and K. F. Wiersum. 2013. Historical development of forest policy in Ethiopia: trends of institutionalization and deinstitutionalization. Land Use Policy 32:186-196. https://doi.org/10.1016/j.landusepol.2012.10.008

Bacon, C. M., C. Getz, S. Kraus, M. Montenegro, and K. Holland. 2012. The social dimensions of sustainability and change in diversified farming systems. Ecology and Society 17(4):41. http:// dx.doi.org/10.5751/ES-05226-170441

Bailey, I., and L. E. Buck. 2016. Managing for resilience: a landscape framework for food and livelihood security and ecosystem services. Food Security 8:477-490. https://doi. org/10.1007/s12571-016-0575-9

Balmford, A., R. E. Green, and J. P. W. Scharlemann. 2005. Sparing land for nature: exploring the potential impact of changes in agricultural yield on the area needed for crop production. Global Change Biology 11(10):1594-1605. https://doi.org/10.1111/ j.1365-2486.2005.001035.x

Berkes F. 2017. Environmental governance for the Anthropocene? Social-ecological systems, resilience, and collaborative learning. Sustainability 9(7):1232. https://doi.org/10.3390/su9071232

Biggs, R., M. Schlüter, and M. L. Schoon. 2015. Principles for building resilience: sustaining ecosystem services in socialecological systems. Cambridge University Press, Cambridge, UK. https://doi.org/10.1017/CBO9781316014240

Brems, E., C. Van der Beken, and S. A. Yimer. 2015. Human rights and development. Legal perspectives from and for Ethiopia. Koninklijke Brill NV, Leiden, The Netherlands. https://doi. org/10.1163/9789004280250

Brussaard, L., P. Caron, B. Campbell, L. Lipper, S. Mainka, R. Rabbinge, D. Babin, and M. Pulleman. 2010. Reconciling biodiversity conservation and food security: scientific challenges for a new agriculture. Current Opinion in Environmental Sustainability 2(1-2):34-42. http://dx.doi.org/10.1016/j.cosust.2010.03.007

Chappell, M. J., and L. A. LaValle. 2011. Food security and biodiversity: can we have both? An agroecological analysis. Agriculture and Human Values 28:3-26. http://dx.doi.org/10.1007/ s10460-009-9251-4

Chilalo, M., and K. F. Wiersum. 2011. The role of non-timber forest products for livelihood diversification in southwest Ethiopia. Ethiopian e-Journal for Research and Innovation Foresight: Agriculture and Forestry 3(1):44-59. [online] URL: http://library.wur.n1/WebQuery/wurpubs/fulltext/182898

Cotula, L., S. Vermeulen, R. Leonard, and J. Keeley. 2009. Land grab or development opportunity? Agricultural investment and international land deals in Africa. IIED/FAO/IFAD, London/ Rome, UK/Italy. [online] URL: http://pubs.iied.org/pdfs/12561IIED. pdf 
CSA/WFP (Ethiopian Central Statistical Agency/World Food Programme). 2014. Ethiopia: comprehensive food security and vulnerability analysis. Physical Planning Department, Addis Ababa, Ethiopia. [online] URL: https://documents.wfp.org/ stellent/groups/public/documents/ena/wfp265490.pdf

Cunneyworth, P. 2001. Managing agricultural resources for biodiversity conservation. Case study of Ethiopia, Kenya, South Africa and Zimbabwe. Environment Liaison Centre International, Kasarani, Kenya. [online] URL: https://www.academia. edu/1614082/Managing Agricultural Resources for Biodiversity Conservation

Daconto, G., and L. N. Sherpa. 2010. Applying scenario planning to park and tourism management in Sagarmatha National Park, Khumbu, Nepal. Mountain Research and Development 30 (2):103-112. https://doi.org/10.1659/MRD-JOURNAL-D-09-00047.1

Desquilbet, M., B. Dorin, and D. Couvet. 2017. Land sharing vs land sparing to conserve biodiversity: how agricultural markets make the difference. Environmental Modeling \& Assessment 22:185-200. https://doi.org/10.1007/s10666-016-9531-5

Dressler, W., J. de Koning, M. Montefrio, and J. Firn. 2016. Land sharing not sparing in the "green economy": the role of livelihood bricolage in conservation and development in the Philippines. Geoforum 76:75-89. https://doi.org/10.1016/j.geoforum.2016.09.003

Edwards, D. P., J. A. Hodgson, K. C. Hamer, S. L. Mitchell, A. H. Ahmad, S. J. Cornell, and D. S. Wilcove. 2010. Wildlife-friendly oil palm plantations fail to protect biodiversity effectively. Conservation Letters 3(4):236-242. https://doi.org/10.1111/ j.1755-263X.2010.00107.X

Federal Democratic Republic of Ethiopia. 2011. Ethiopia's climate-resilient green economy: green economy strategy. Federal Democratic Republic of Ethiopia, Addis Ababa, Ethiopia. [online] URL: https://www.undp.org/content/dam/ethiopia/docs/ Ethiopia\%20CRGE.pdf

Fischer, J., D. J. Abson, A. Bergsten, N. F. Collier, I. Dorresteijn, J. Hanspach, K. Hylander, J. Schultner, and F. Senbeta. 2017. Reframing the food- biodiversity challenge. Trends in Ecology \& Evolution 32(5):335-345. http://dx.doi.org/10.1016/j.tree.2017.02.009 1

Fischer, J., B. Brosi, G. C. Daily, P. R. Ehrlich, R. Goldman, J. Goldstein, D. B. Lindenmater, A. D. Manning, H. A. Mooney, L. Pejchar, J. Ranganathan, and H. Tallis. 2008. Should agricultural policies encourage land sparing or wildlife-friendly farming? Frontiers in Ecology and the Environment 6(7):380-385. https://doi.org/10.1890/070019

Fischer, J., F. Senbeta, I. Dorresteijn, J. Hanspach, T. S. Jiren, and J. Schultner. 2018. Envisioning the future for southwestern Ethiopia. A book by The Sustainable Landscapes Group with Contributions by local experts. Pensoft Publishers, Sofia, Bulgaria.

Flynn, M., J. D. Ford, T. Pearce, S. L. Harper, and IHACC Research Team. 2018. Participatory scenario planning and climate change impacts, adaptation and vulnerability research in the Arctic. Environmental Science \& Policy 79:45-53. http://dx. doi.org/10.1016/j.envsci.2017.10.012

Foley, J. A., R. DeFries, G. P. Asner, C. Barford, G. Bonan, S. R. Carpenter, F. S. Chapin, M. T. Coe, G. C. Daily, H. K. Gibbs, et al. 2005. Global consequences of land use. Science 309:570-574. http://dx.doi.org/10.1126/science. 1111772

Folke, C., J. Colding, and F. Berkes. 2003. Synthesis: building resilience and adaptive capacity in social-ecological systems. Pages 352-387 in F. Berkes, J. Colding, and C. Folke, editors. Navigating social-ecological systems: building resilience for complexity and change. Cambridge University Press, Cambridge, UK. http://dx.doi.org/10.1017/cbo9780511541957.020

Food and Agricultural Organization (FAO). 2018. The state of food security and nutrition in the world. Building climate resilience for food security and nutrition. FAO, Rome, Italy. [online] URL: http://www.fao.org/3/i9553en/i9553en.pdf

Freeth, R., and S. Drimie. 2016. Participatory scenario planning: from scenario 'stakeholders' to scenario 'owners.' Environment: Science and Policy for Sustainable Development 58(4):32-43. http://dx.doi.org/10.1080/00139157.2016.1186441

Gatzweiler, F. W. 2005. Institutionalizing biodiversity conservation - the case of Ethiopian coffee forests. Conservation \& Society 3(1):201-223.

Gebreselassie, S. 2006. Intensification of smallholder agriculture in Ethiopia: options and scenarios. Discussion paper No. 007. Future Agricultures Consortium Secretariat, Institute of Development Studies, Brighton, UK. [online] URL: https://www. future-agricultures.org/wp-content/uploads/pdf-archive/ FAC Discussion Paper 007.pdf

Gebreselassie, S., and K. Sharp. 2007. Commercialization of smallholder agriculture in selected Tef-growth area of Ethiopia. Ethiopian Journal of Economics 16(1):116-116. https://doi. org/10.4314/eje.v16i1.39824

Glamann, J., J. Hanspach, D. J. Abson, N. Collier, and J. Fischer. 2017. The intersection of food security and biodiversity conservation: a review. Regional Environmental Change 17:1303-1313. https://doi.org/10.1007/s10113-015-0873-3

Godfray, H. C. J., J. R. Beddington, I. R. Crute, L. Haddad, D. Lawrence, J. F. Muir, J. Pretty, S. Robinson, S. M. Thomas, and C. Toulmin. 2010. Food security: the challenge of feeding 9 billion people. Science 327(5967):812-818. https://doi.org/10.1126/ science. 1185383

Gonthier, D. J., K. K. Ennis, S. Farinas, H.-Y. Hsieh, A. L. Iverson, P. Bata'ry, J. Rudolphi, T. Tscharntke, B. J. Cardinale, and I. Perfecto. 2014. Biodiversity conservation in agriculture requires a multi-scale approach. Proceedings of the Royal Society B. Biological Sciences 281(1791). http://dx.doi.org/10.1098/rspb.2014.1358

Gove, A. D., K. Hylander, S. Nemomisa, and A. Shimelis. 2008. Ethiopian coffee cultivation-implications for bird conservation and environmental certification. Conservation Letters 1 (5):208-216. http://dx.doi.org/10.1111/j.1755-263X.2008.00033. $\underline{\mathrm{x}}$

Grau, R., T. Kuemmerle, and L. Macchi. 2013. Beyond 'land sparing vs. land sharing': environmental heterogeneity, globalization and the balance between agriculture and nature conservation. Current Opinion in Environmental Sustainability 5:477-483. https://doi.org/10.1016/i.cosust.2013.06.001 
Green, R. E., S. J. Cornell, J. P. W. Scharlemann, and A. Balmford. 2005. Farming and the fate of wild nature. Science 307 (5709):550-555. https://doi.org/10.1126/science.1106049

Hanspach, J., T. Hartel, A. I. Milcu, F. Mikulcak, I. Dorresteijn, J. Loos, H. von Wehrden, T. Kuemmerle, D. Abson, A. KovácsHostyánszki, A. Báldi, and J. Fischer. 2014. A holistic approach to studying social-ecological systems and its application to Southern Transylvania. Ecology and Society 19(4):32. http://dx. doi.org/10.5751/es-06915-190432

Henrichs, T., M. Zurek, B. Eickhout, K. Kok, C. RaudseppHearne, T. Ribeiro, D. van Vuuren, and A. Volkery. 2010. Scenario development and analysis for forward-looking ecosystem assessments. Pages 151-220 in N. Ash, H. Blanco, C. Brown, K. Garcia, T. Henrichs, N. Lucas, C. Ruadsepp-Heane, R. D. Simpson, R. Scholes, T. Tomich, B. Vira, and M. Zurek, editors. Ecosystems and human well-being: a manual for assessment practitioners. Island, Washington, D.C., USA.

Hersperger, A. M., M. Gennaio, P. H. Verburg, and M. Bü'rgi. 2011. Feedback loops in conceptual models of land change: lost in complexity? Ecology and Society 16(2):r1. https://doi. org/10.5751/es-04204-1602r1

Holt-Giménez, E., and M. A. Altieri. 2013. Agroecology, food sovereignty and the New Green Revolution. Agroecology and Sustainable Food Systems 37(1):90-102. https://doi. org/10.1080/10440046.2012.716388

Horne, F., F. Mousseau, O. Metho, A. Mittal, and D. Shepard. 2011. Understanding land investment deals in Africa. The Oakland Institute, Oakland, California, USA. [online] URL: https://www. oaklandinstitute.org/sites/oaklandinstitute.org/files/

OI Ethiopa Land Investment report.pdf

Hylander, K., T. G. Ango, L. Börjeson, P. Hambäck, D. Lemessa, S. Nemomissa, U. Samnegård, and F. Senbeta. 2014. Nature, people and agriculture in southwestern Ethiopia: the interaction between small scale agriculture and the diversity of organisms in mosaic landscapes. Stockholm University, Stockholm, Sweden, and Addis Ababa University, Addis Ababa, Ethiopia. ISBN: 978-91-7540-172-0.

Järnberg, L., E. Enfors Kautsky, L. Dagerskog, and P. Olsson. 2018. Land use policy green niche actors navigating an opaque opportunity context: prospects for a sustainable transformation of Ethiopian agriculture. Land Use Policy 71:409-421. https://doi. org/10.1016/j.landusepol.2017.11.053

Jiren, T. S., A. Bergsten, I. Dorresteijn, N. F. Collier, J. Leventon, and J. Fischer. 2018a. Integrating food security and biodiversity governance: a multi-level social network analysis in Ethiopia. Land Use Policy 78:420-429. https://doi.org/10.1016/j.

landusepol.2018.07.014

Jiren, T. S., I. Dorresteijn, J. Hanspach, J. Schultner, A. Bergesten, A. Manlosa, N. W. Jager, F. Senbeta, and J. Fischer. 2020. Alternative discourses around the governance of food security: a case study from Ethiopia. Global Food Security 24:100338. https:// doi.org/10.1016/i.gfs.2019.100338

Jiren, T. S., I. Dorresteijn, J. Schultner, and J. Fischer. 2018b. The governance of land use strategies: institutional and social dimensions of land sparing and land sharing. Conservation Letters 11:e12429. https://doi.org/10.1111/conl.12429
Kerr, R. B., H. Nyantakyi-Frimpong, E. Lupafya, and L. Dakishoni. 2016. Food sovereignty, agroecology and resilience: competing or complementary frames? In Global governancel politics, climate justice \& agrarian/social justice: linkages and challenges. International Institute of Social Studies,

The Hague, The Netherlands.

Kremen, C. 2015. Reframing the land-sparing/land-sharing debate for biodiversity conservation. Annals of the New York Academy of Sciences 1355(1):52-76. https://doi.org/10.1111/ nyas. 12845

Konstantinidis, C. 2018. Capitalism in green disguise: the political economy of organic farming in the European Union. Review of Radical Political Economics 50(4):1-23. https://doi. org/10.1177/0486613417717482

Koohafkan, P., M. A. Altieri, and E. Holt Gimenez. 2012. Green agriculture: foundations for biodiverse, resilient and productive agricultural systems. International Journal of Agricultural Sustainability 10:61-75. https://doi.org/10.1080/14735903.2011.610206

Lemessa, D., P. A. Hambäck, and K. Hylander. 2015. The effect of local and landscape level land-use composition on predatory arthropods in a tropical agricultural landscape. Landscape Ecology 30:167-80. https://doi.org/10.1007/s10980-014-0115-y

Matson, P. A., and P. M. Vitousek. 2006. Agricultural intensification: will land spared from farming be land spared for nature? Conservation Biology 20(3):709-710. https://doi. org/10.1111/j.1523-1739.2006.00442.x

Mbunda, R. 2017. The developmental state and food sovereignty in Tanzania. Agrarian South: Journal of Political Economy 5 (2-3):265-291. https://doi.org/10.1177/2277976017700210

McKeon, N. 2014. Food security governance: empowering communities, regulating corporations. Routledge, London, UK. https://doi.org/10.4324/9781315882529

Meadows, D. H. 1999. Leverage points: places to intervene in a systems. The Sustainability Institute, Hartland, Vermont, USA.

Ministry of Finance and Economic Development (MOFED). 2003. Rural development policy and strategies. The Federal Democratic Republic of Ethiopia, Addis Adaba, Ethiopia. [online] URL: https://www.gafspfund.org/sites/default/files/ inline-files/6.\%20Ethiopia Agriculture $\% 20$ strategy.pdf

Ministry of Finance and Economic Development (MOFED). 2010. The Federal Democratic Republic of Ethiopia growth and transformation plan 2010/11-2014/15. The Federal Democratic Republic of Ethiopia, Addis Adaba, Ethiopia. [online] URL: http://extwprlegs1.fao.org/docs/pdf/eth144893.pdf

Mittermeier, R. A., W. R. Turner, F. W. Larsen, T. M. Brooks, and C. Gascon. 2011. Global biodiversity conservation: the critical role of hotspots. Pages 3-22 in F. E. Zachos and J. C. Habel, editors. Biodiversity hotspots. Springer-Verlag, Berlin, Germany. http://dx.doi.org/10.1007/978-3-642-20992-5 1

Morrison, K., and J. E. FitzGibbon. 2014. Adaptive governance of dynamic social-ecological systems: the case of the Ontario Environmental Farm Plan (1992-2011). Agroecology and Sustainable Food Systems 38(4):378-409. https://doi. org/10.1080/21683565.2013.870627 
New Partnership for Africa's Development (NEPAD). 2003. Comprehensive Africa agriculture development programme. NEPAD Secretaria, Midrand, South Africa. [online] URL: http:// www.fao.org/nr/water/aquastat/sirte2008/NEPAD-CAADP $\% 202003$. pdf

Nyéléni Declaration. 2007. Declaration of the Forum for Food Sovereignty. Nyéléni, Sélingué, Mali. [online] URL: https:// nyeleni.org/spip.php?article290

Olsson, P., C. Folke, V. Galaz, T. Hahn, and L. Schultz. 2007. Enhancing the fit through adaptive co-management: creating and maintaining bridging functions for matching scales in the Kristianstads Vattenrike Biosphere Reserve, Sweden. Ecology and Society 12(1):28. http://dx.doi.org/10.5751/ES-01976-120128

Oromia Bureau of Finance and Economic Development (OBFED). 2012. Condensed physical geography of Oromiya. Physical Planning Department, Addis Ababa, Ethiopia.

Ostrom, E. 2009. A general framework for analyzing sustainability of social-ecological systems. Science 325:419-422. http://dx.doi.org/10.1126/science.1172133

Oteros-Rozas, E., B. Martín-López, T. Daw, E. L. Bohensky, J. Butler, R. Hill, J. Martin-Ortega, A. Quinlan, F. Ravera, I. RuizMallén, M. Thyresson, J. Mistry, I. Palomo, G. D. Peterson, T. Plieninger, K. A. Waylen, D. Beach, I. C. Bohnet, M. Hamann, J. Hanspach, K. Hubacek, S. Lavorel, and S. Vilardy. 2015. Participatory scenario planning in place-based social-ecological research: insights and experiences from 23 case studies. Ecology and Society 20(4):32. http://dx.doi.org/10.5751/ES-07985-200432

Pender, J., and D. Alemu. 2007. Determinants of smallholder commercialization of food crops: theory and evidence from Ethiopia. IFPRI Discussion Paper 00745. International Food Policy Research Institute, Washington, D.C., USA. [online] URL: https://www.ifpri.org/publication/determinants-smallholdercommercialization-food-crops

Phalan, B., M. Onial, A. Balmford, and R. E. Green. 2011. Reconciling food production and biodiversity conservation: land sharing and land sparing compared. Science 333(6047):1289-1291. https://doi.org/10.1126/science.1208742

Pimbert, M. P. 2009. Towards food sovereignty: reclaiming autonomous food systems. International Institute for Environment and Development, London, UK. [online] URL: https://www.iied. org/towards-food-sovereignty-reclaiming-autonomous-food-systems

Plummer, R., D. R. Armitage, and R. C. de Loë. 2013. Adaptive comanagement and its relationship to environmental governance. Ecology and Society 18(1):21. https://doi.org/10.5751/ES-05383-180121

Rahmato, D. 2011. Land to investors: large-scale land transfers in Ethiopia Addis Ababa. Forum for Social Sciences 1-36. [online] URL: https://mokoro.co.uk/wp-content/uploads/ land to investors ethiopia rahmato.pdf

Rudel, T. K., K. T. Roberts, and J. Carmin. 2011. Political economy of the environment. Annual Review of Sociology 37:221-238. https://doi.org/10.1146/annurev.soc.012809.102639

Shiva, V. 2011. The violence of green revolution: Third World agriculture, ecology and politics. Zed Books, London, UK.
Sunderland, T. C. H. 2011. Food security: Why is biodiversity important? International Forestry Review 13(3):265-274. https:// doi.org/10.1505/146554811798293908

Tadesse, G., E. Zavaleta, and C. Shennan. 2014. Coffee landscapes as refugia for native woody biodiversity as forest loss continues in southwest Ethiopia. Biological Conservation 169:384-391. http://dx.doi.org/10.1016/j.biocon.2013.11.034

Tengö, M., and K. Belfrage. 2004. Local management practices for dealing with change and uncertainty: a cross-scale comparison of cases in Sweden and Tanzania. Ecology and Society 9(3):4. https://doi.org/10.5751/ES-00672-090304

United Nations (UN). 2015a. Transforming our world: the 2030 agenda for sustainable development. Resolution adopted by the General Assembly on 25 September 2015. UN, New York, New York, USA. [online] URL: http://www.un.org/ga/search/ view doc.asp?symbol=A/RES/70/1\&Lang=E

United Nations (UN). 2015b. World population prospects: key findings and advance tables. 2015 revision. Working Paper No. ESA/P/WP.241. The Department of Economic and Social Affairs of the United Nations, New York, New York, USA. [online] URL: https://esa.un.org/unpd/wpp/publications/files/key_findings_wpp_2015. pdf https://doi.org/10.18356/08b807d4-en

Visser, O., and M. Spoor. 2011. Land grabbing in post-Soviet Eurasia: the world's largest agricultural land reserves at stake. Journal of Peasant Studies 38(2):299-323. https://doi. org/10.1080/03066150.2011.559010

Wittman, H., M. J. Chappell, D. J. Abson, R. B. Kerr, J. Blesh, J. Hanspach, I. Perfecto, and J. Fischer. 2017. A social-ecological perspective on harmonizing food security and biodiversity conservation. Regional Environmental Change 17:1291-1301. http://dx.doi.org/10.1007/s10113-016-1045-9

Zoomers, A. 2010. Globalisation and the foreignisation of space: seven processes driving the current global land grab. Journal of Peasant Studies 37(2):429-447. https://doi.org/10.1080/03066151003595325 


\section{Appendix 1}

Table A1.1. List of stakeholders who participated in the scenario workshops. The table lists the names of stakeholder organizations that participated in the three rounds of workshops. With few exceptions, each stakeholder was represented by one senior staff member. Only few of these representatives were replaced across workshop rounds due to personnel turnover.

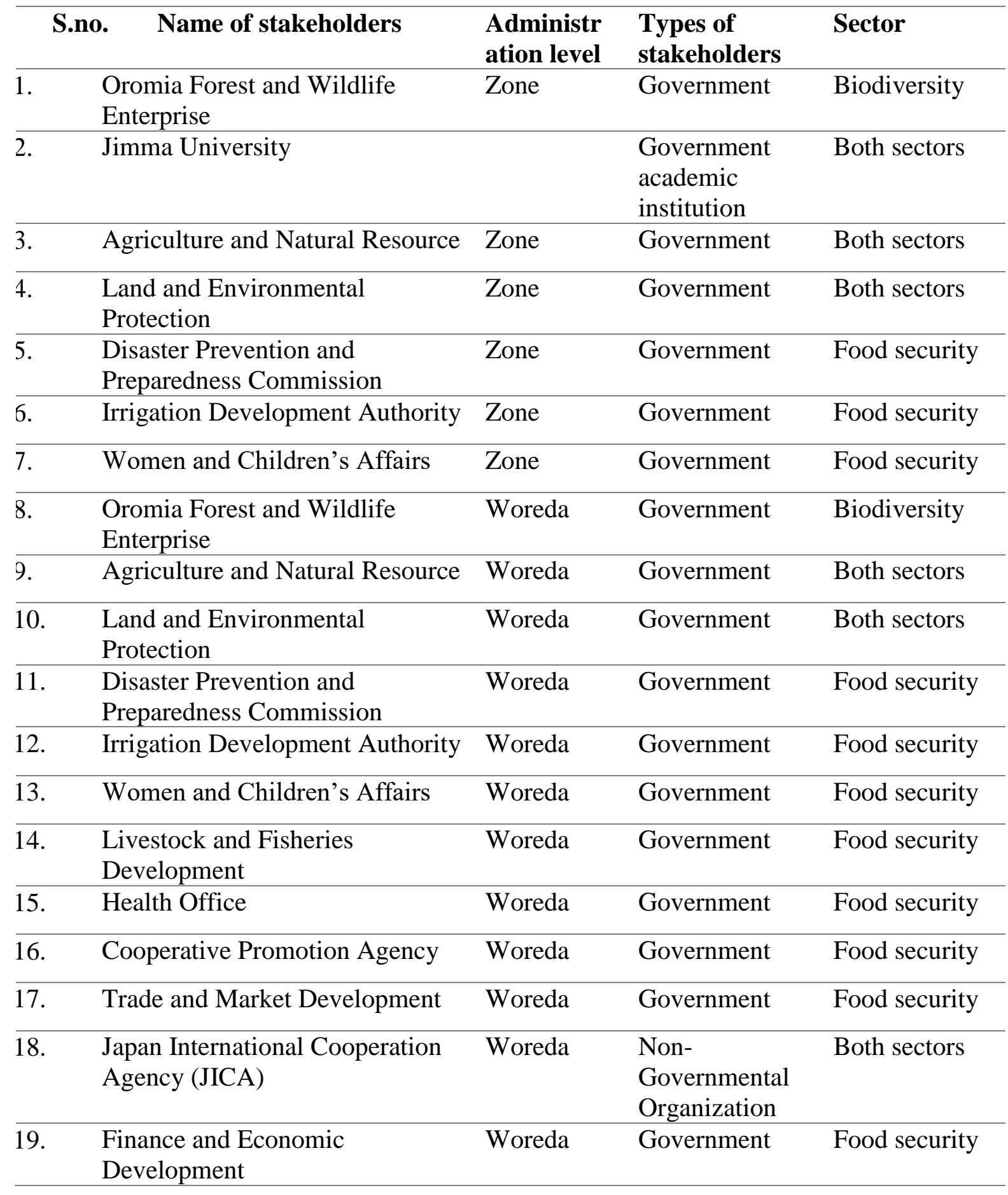




\begin{tabular}{|c|c|c|c|c|}
\hline 20. & Administration office & Woreda & Government & Food security \\
\hline 21. & $\begin{array}{l}\text { Micro and Small Enterprise } \\
\text { Development Agency (IMX) }\end{array}$ & Woreda & Government & Food security \\
\hline 22. & $\begin{array}{l}\text { Administration and Security } \\
\text { Office }\end{array}$ & Woreda & Government & Food security \\
\hline 23. & $\begin{array}{l}\text { Oromia Credit and Finance Share } \\
\text { Company (WALQO) }\end{array}$ & Woreda & Government & Food security \\
\hline 24. & Rural Road Authority & Woreda & Government & Food security \\
\hline 25. & $\begin{array}{l}\text { Arga Multi-purpose Farmers } \\
\text { Union }\end{array}$ & Woreda & $\begin{array}{l}\text { Community- } \\
\text { based Union }\end{array}$ & Both sectors \\
\hline 26. & Female farmers group & Kebele & Government & Both sectors \\
\hline 27. & $\begin{array}{l}\text { Agricultural and Natural } \\
\text { Resources Development Agents } \\
\text { (Development Agents) }\end{array}$ & Kebele & Government & Both sectors \\
\hline 28. & Health Extension & Kebele & Government & Both sectors \\
\hline 29. & Religious leaders & Kebele & Community & Both sectors \\
\hline 30. & $\begin{array}{l}\text { Kebele leaders (municipal } \\
\text { leaders) }\end{array}$ & Kebele & Government & Both sectors \\
\hline 31. & Jawi Multi-purpose Cooperative & Kebele & $\begin{array}{l}\text { Community- } \\
\text { based } \\
\text { cooperative }\end{array}$ & Both sectors \\
\hline 32. & Male farmers group & Kebele & Community & Both sectors \\
\hline 33. & $\begin{array}{l}\text { Community Network Leaders } \\
\text { (Gare Leaders) }\end{array}$ & Kebele & Community & Both sectors \\
\hline 34. & $\begin{array}{l}\text { Land and Environmental } \\
\text { Protection Development Agent }\end{array}$ & Kebele & Government & Both sectors \\
\hline 35. & Elementary school teachers & Kebele & Government & Both sectors \\
\hline
\end{tabular}


Table A1.2. Key features of the four scenarios.

\begin{tabular}{|c|c|c|c|c|}
\hline Feature & $\begin{array}{l}\text { Gain over } \\
\text { grain: local } \\
\text { cash crops }\end{array}$ & $\begin{array}{l}\text { Mining Green } \\
\text { gold: coffee } \\
\text { investors }\end{array}$ & $\begin{array}{l}\text { Coffee and } \\
\text { conservation: a } \\
\text { biosphere } \\
\text { reserve }\end{array}$ & $\begin{array}{l}\text { Food first: } \\
\text { intensive } \\
\text { farming and } \\
\text { forest protection }\end{array}$ \\
\hline $\begin{array}{l}\text { Connectedne } \\
\text { ss (outside } \\
\text { landscape) }\end{array}$ & $\begin{array}{l}\text { High to national } \\
\text { market }\end{array}$ & $\begin{array}{l}\text { High to global } \\
\text { market }\end{array}$ & $\begin{array}{l}\text { Medium- to } \\
\text { global and } \\
\text { national green } \\
\text { institutions }\end{array}$ & $\begin{array}{l}\text { High to national } \\
\text { market }\end{array}$ \\
\hline $\begin{array}{l}\text { Main } \\
\text { governance } \\
\text { mechanism }\end{array}$ & $\begin{array}{l}\text { Smallholder } \\
\text { commercializati } \\
\text { on (national } \\
\text { market) }\end{array}$ & $\begin{array}{l}\text { Market based } \\
\text { economy via } \\
\text { import } \\
\text { substitution } \\
\text { and export } \\
\text { promotion } \\
\text { (global market) }\end{array}$ & $\begin{array}{l}\text { Smallholder } \\
\text { sovereignty and } \\
\text { green economy } \\
\text { (bottom-up } \\
\text { participatory) }\end{array}$ & $\begin{array}{l}\text { Smallholder } \\
\text { intensification and } \\
\text { regional market } \\
\text { integration with } \\
\text { state intervention }\end{array}$ \\
\hline Main actors & $\begin{array}{l}\text { Local } \\
\text { community, } \\
\text { merchants, } \\
\text { extension } \\
\text { agents. }\end{array}$ & $\begin{array}{l}\text { domestic as } \\
\text { well as foreign } \\
\text { investors with } \\
\text { big capital }\end{array}$ & $\begin{array}{l}\text { Community- } \\
\text { based } \\
\text { institutions, } \\
\text { green-build } \\
\text { ngos, extension } \\
\text { workers }\end{array}$ & $\begin{array}{l}\text { Input marketing } \\
\text { companies, } \\
\text { cooperatives }\end{array}$ \\
\hline $\begin{array}{l}\text { Maintaining } \\
\text { feedbacks }\end{array}$ & $\begin{array}{l}\text { Commercializat } \\
\text { ion, and profits }\end{array}$ & $\begin{array}{l}\text { Economies of } \\
\text { scale, profit } \\
\text { and efficiency }\end{array}$ & $\begin{array}{l}\text { Improved } \\
\text { natural capital, } \\
\text { values }\end{array}$ & $\begin{array}{l}\text { Intensification, } \\
\text { modernization } \\
\text { and profit }\end{array}$ \\
\hline Strengths & $\begin{array}{l}\text { Improved living } \\
\text { standards, } \\
\text { infrastructure } \\
\text { and public } \\
\text { services }\end{array}$ & $\begin{array}{l}\text { National export } \\
\text { earning, , } \\
\text { infrastructural } \\
\text { and service } \\
\text { development, } \\
\text { employment }\end{array}$ & $\begin{array}{l}\text { Sustainable } \\
\text { development, } \\
\text { resilience, and } \\
\text { social justice }\end{array}$ & $\begin{array}{l}\text { Improved food } \\
\text { supply, } \\
\text { smallholders } \\
\text { income, forest } \\
\text { protection }\end{array}$ \\
\hline Weaknesses & $\begin{array}{l}\text { Inequality, } \\
\text { market } \\
\text { dependence } \\
\text { Rice } \\
\text { fluctuation, } \\
\text { mono-cropping } \\
\text { and less } \\
\text { resilience }\end{array}$ & $\begin{array}{l}\text { Low resilience } \\
\text { to market } \\
\text { fluctuations } \\
\text { and climate } \\
\text { change, } \\
\text { decreased } \\
\text { social and } \\
\text { natural capitals }\end{array}$ & $\begin{array}{l}\text { Slow economic } \\
\text { growth }\end{array}$ & $\begin{array}{l}\text { Loss of natural } \\
\text { capital, lack of } \\
\text { resilience, lack of } \\
\text { food diversity }\end{array}$ \\
\hline
\end{tabular}




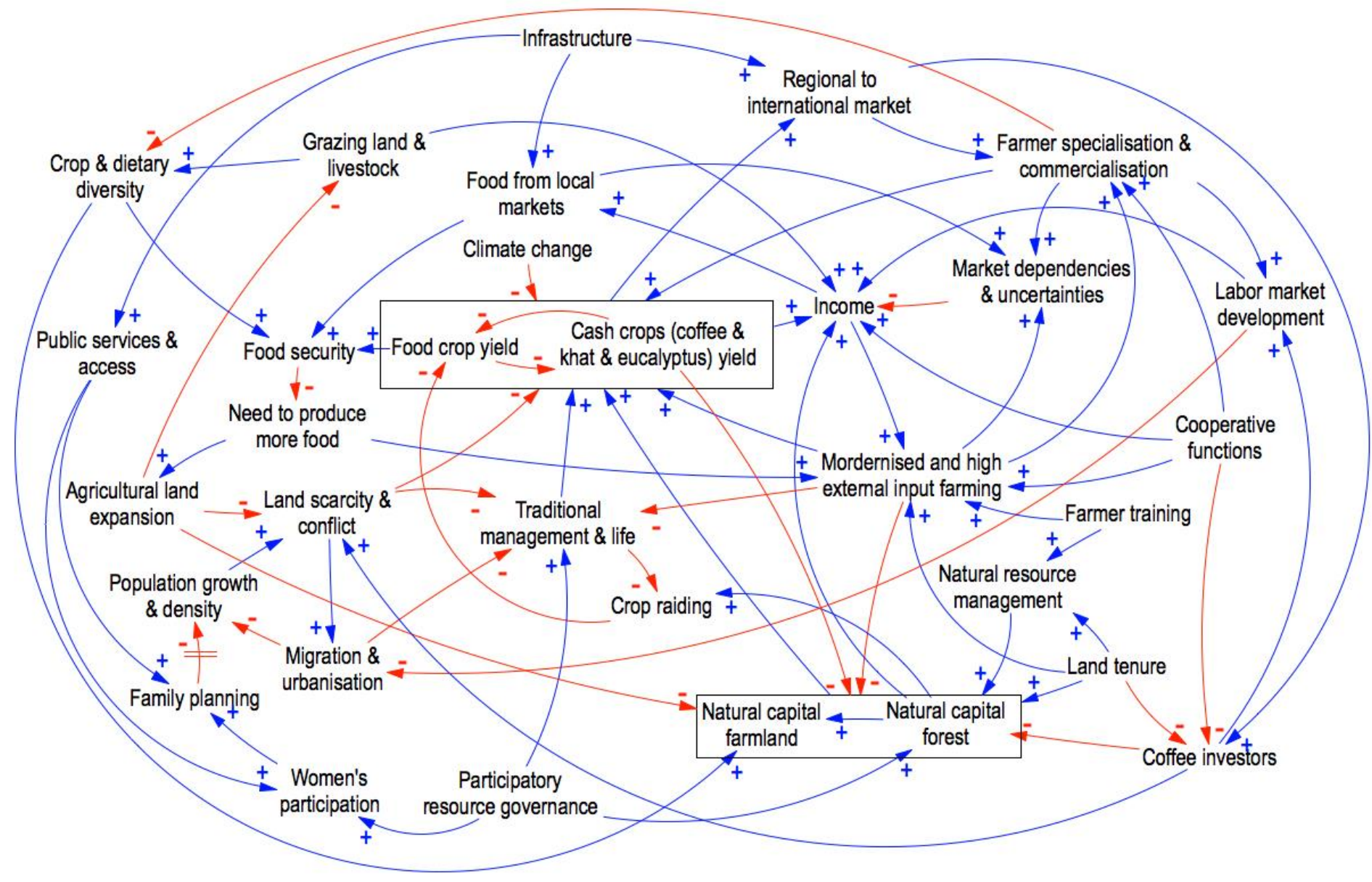

Figure A1.1. Causal loop diagram indicating how drivers of change in the system affect one another. Red arrows with a negative sign $\left(\rightarrow{ }^{-}\right)$ indicate a reducing effect and blue arrows with a positive sign $\left(\rightarrow^{+}\right)$indicate an enhancing effect of one variable onto another. The crossed arrow between family planning and population growth $(\hat{\neq}-)$ indicates a temporal delay between the variables. . 
Table A1.3. Description of the main drivers of change included in the causal loop diagram

\begin{tabular}{|c|c|c|}
\hline Sno & $\begin{array}{l}\text { Name of drivers of } \\
\text { change }\end{array}$ & Description \\
\hline 1. & Infrastructure & Improvement in the roads, health services, schools \\
\hline 2. & $\begin{array}{l}\text { Regional to the } \\
\text { international market }\end{array}$ & $\begin{array}{l}\text { Integration of local people to the regional and global market } \\
\text { through the export of commodities produced in the landscape }\end{array}$ \\
\hline 3. & $\begin{array}{l}\text { Farmers } \\
\text { specialization and } \\
\text { commercialization }\end{array}$ & $\begin{array}{l}\text { Increased specialization of farmers into few marketable crops, } \\
\text { and the decision of farmers to increasingly integrate into to } \\
\text { market system through purchases of inputs and sale of } \\
\text { commercial crops. }\end{array}$ \\
\hline 4. & $\begin{array}{l}\text { Market } \\
\text { dependencies and } \\
\text { uncertainties }\end{array}$ & $\begin{array}{l}\text { The increasing dependence of market by farmers to purchase } \\
\text { inputs and sell products, and also uncertainty in the market } \\
\text { price. Variables such as input and output market fluctuation, } \\
\text { price volatility and thin and missing markets are categorized } \\
\text { under this driver of change }\end{array}$ \\
\hline 5. & $\begin{array}{l}\text { Labor market } \\
\text { development }\end{array}$ & $\begin{array}{l}\text { Increased access to educated human resources, increased } \\
\text { employment opportunity are included under this driver }\end{array}$ \\
\hline 6. & $\begin{array}{l}\text { Cooperative } \\
\text { functions }\end{array}$ & $\begin{array}{l}\text { Expansion of farmers cooperatives, expansion of financial } \\
\text { services such as microfinance, and small and micro } \\
\text { enterprises }\end{array}$ \\
\hline 7. & Farmer training & $\begin{array}{l}\text { Improved regular training to farmers, and expansion of } \\
\text { Farmers Training Centers }\end{array}$ \\
\hline 8. & $\begin{array}{l}\text { Natural resource } \\
\text { management }\end{array}$ & $\begin{array}{l}\text { Conservation of biodiversity, soil and water conservation, and } \\
\text { forest protection variables were coded under these drivers of } \\
\text { change }\end{array}$ \\
\hline 9. & Land tenure & $\begin{array}{l}\text { Improved security of land ownership, the right not to be } \\
\text { evicted from own land, increased access and control over } \\
\text { farmland were among the variables coded under this driver of } \\
\text { change }\end{array}$ \\
\hline 10. & Coffee investors & $\begin{array}{l}\text { Increased in the number of private companies (both domestic } \\
\text { and international) investing in commercial coffee production } \\
\text { in the landscape }\end{array}$ \\
\hline 11. & $\begin{array}{l}\text { Natural capital } \\
\text { farmland }\end{array}$ & $\begin{array}{l}\text { Improved conservation of farmland biodiversity, quality of } \\
\text { farmland natural resources including farmland productivity }\end{array}$ \\
\hline 12. & $\begin{array}{l}\text { Natural capital } \\
\text { forest }\end{array}$ & $\begin{array}{l}\text { Improved conservation of forestland biodiversity, quality of } \\
\text { forest in terms of species richness and diversity }\end{array}$ \\
\hline 13. & Crop raiding & $\begin{array}{l}\text { Increased harmful wild animals, strengthened policy of ban } \\
\text { hunting, increased crop loss by wild animals }\end{array}$ \\
\hline
\end{tabular}




\begin{tabular}{|c|c|c|}
\hline 14. & $\begin{array}{l}\text { Modernizing and } \\
\text { high external input } \\
\text { farming }\end{array}$ & $\begin{array}{l}\text { Increased intensification of the farm, increased use of } \\
\text { inorganic fertilizers and agrochemicals, mechanization of } \\
\text { farmland were considered under these drivers of change }\end{array}$ \\
\hline 15. & Income & $\begin{array}{l}\text { Increased income from commercialization of cash crops } \\
\text { (coffee, eucalyptus, khat) and food crops (maize, sorghum, } \\
\text { and teff) }\end{array}$ \\
\hline 16. & Cash crops yield & $\begin{array}{l}\text { Increased production and yield of cash crops (coffee, } \\
\text { eucalyptus, khat) }\end{array}$ \\
\hline 17. & Food crops yield & $\begin{array}{l}\text { Increased production and yield of cash crops (maize, } \\
\text { sorghum, and teff) }\end{array}$ \\
\hline 18. & $\begin{array}{l}\text { Food from the local } \\
\text { market }\end{array}$ & $\begin{array}{l}\text { Increased availability of food crops produced in other places, } \\
\text { changes in diet to food purchased from the market than } \\
\text { producing their food }\end{array}$ \\
\hline 19. & Climate change & $\begin{array}{l}\text { Increased weather variability (rainfall pattern), increased long } \\
\text { term change in climate elements, increased effects of climate } \\
\text { change such as drought, and floods }\end{array}$ \\
\hline 20. & $\begin{array}{l}\text { Grazing land and } \\
\text { livestock }\end{array}$ & $\begin{array}{l}\text { improved in grazing land, improved in access to communal } \\
\text { grazing land, increased intensive livestock production, }\end{array}$ \\
\hline 21. & $\begin{array}{l}\text { Crop and dietary } \\
\text { diversity }\end{array}$ & $\begin{array}{l}\text { Improved in the types of crops grown, improved in food } \\
\text { diversity }\end{array}$ \\
\hline 22. & $\begin{array}{l}\text { Public services and } \\
\text { access }\end{array}$ & $\begin{array}{l}\text { Increased access to market information, increased access to } \\
\text { climate information, increased access to low-cost food }\end{array}$ \\
\hline 23. & Food security & $\begin{array}{l}\text { Improved food production and availability, improved access } \\
\text { to food, improved utilization of food, and improved } \\
\text { uninterrupted supply of food }\end{array}$ \\
\hline 24. & $\begin{array}{l}\text { Need to produce } \\
\text { more food }\end{array}$ & $\begin{array}{l}\text { Increasing the yield of food crops, the need to produce more } \\
\text { food }\end{array}$ \\
\hline 25. & $\begin{array}{l}\text { Agricultural land } \\
\text { expansion }\end{array}$ & Increased agricultural area, expansion of farmland \\
\hline 26. & $\begin{array}{l}\text { Land scarcity and } \\
\text { conflict }\end{array}$ & $\begin{array}{l}\text { Increased shortage of farmland, increased conflict between } \\
\text { farmers and investors, increased conflict for access to } \\
\text { resources }\end{array}$ \\
\hline 27. & $\begin{array}{l}\text { Population growth } \\
\text { and density }\end{array}$ & $\begin{array}{l}\text { Increased population, increased fertility rate, increased } \\
\text { number of people per unit area }\end{array}$ \\
\hline 28. & $\begin{array}{l}\text { Migration and } \\
\text { urbanization }\end{array}$ & $\begin{array}{l}\text { Increased number of youth migrating to urban areas and } \\
\text { outside the country (usually to Arab countries to work as a } \\
\text { housemaid), increased number of jobless people in the nearby } \\
\text { urban areas }\end{array}$ \\
\hline 29. & Family planning & Increased use of family planning \\
\hline
\end{tabular}




\begin{tabular}{lll}
\hline 30. & $\begin{array}{l}\text { Women's } \\
\text { participation }\end{array}$ & $\begin{array}{l}\text { Improved women's participation in household decision } \\
\text { making, increased participation of women in community } \\
\text { services and works }\end{array}$ \\
\hline 31. & $\begin{array}{l}\text { Participatory } \\
\text { resource } \\
\text { governance }\end{array}$ & $\begin{array}{l}\text { Increased community participation in resource management } \\
\text { (forest and communal lands) }\end{array}$ \\
\hline 32. & $\begin{array}{l}\text { Traditional } \\
\text { management and } \\
\text { life }\end{array}$ & $\begin{array}{l}\text { Improved trust between communities, increased use if local } \\
\text { informal institutions, increased participatory land } \\
\text { management, improved cooperation between the } \\
\text { communities. }\end{array}$ \\
\hline
\end{tabular}


Table A1.4. Main past drivers of change summarized based on their category

\begin{tabular}{ll}
$\begin{array}{l}\text { The major category of drivers } \\
\text { of change in the past }\end{array}$ & $\begin{array}{l}\text { Examples of past drivers of change under each } \\
\text { category }\end{array}$ \\
\hline Local living conditions \\
\hline Social trust \\
\hline Traditions \\
\hline Population growth \\
\hline Education \\
\hline Food security \\
\hline Farmers awareness about the farming system \\
\hline Migration \\
\hline Health education and services \\
\hline Dietary diversity \\
\hline Individualism \\
\hline Family planning \\
\hline Agricultural training \\
\hline Youth cooperation \\
\hline Khat consumption \\
\hline Underage marriage \\
\hline Religious understanding and expansion \\
\hline Mothers and child mortality \\
\hline Commercialization of crops \\
\hline Income and financial access \\
\hline Coffee and crop market \\
\hline Employment \\
\hline Market development and access \\
\hline Income from forest products \\
\hline Cooperative functioning \\
\hline Coffee investors \\
\hline Khat production \\
\hline Microfinance programs \\
\hline Land-use \\
\hline Forest cover \\
\hline Climate change \\
\hline Coffee productivity \\
\hline Food crop productivity \\
\hline Wildanimal population \\
\hline Soil quality and fertility \\
\hline Pollution \\
\hline Plantation of trees \\
\hline Crop disease and insect pests \\
\hline Land use planning \\
\hline Economic changes
\end{tabular}




\begin{tabular}{ll}
\hline & Weather and Rainfall pattern \\
\hline Agricultural expansion \\
\hline Modernized farming \\
\hline Phone network \\
\hline Roads and transport infrastructure \\
\hline Access to farm technologies and inputs \\
\hline Access to energy and power/electricity \\
\hline Agricultural research \\
\hline Access to social media and information \\
\hline Gender equality \\
\hline Participation in decision-making \\
\hline \begin{tabular}{l} 
Land-use rights \\
\hline Solitical and governance \\
changes
\end{tabular} & Security and conflict \\
\hline Stakeholders plurality \\
\hline Corruption and nepotism \\
\hline Freedom of the community \\
\hline Political awareness and participation \\
\hline Rule and policy enforcement \\
\hline Below kebele community structures \\
\hline Agricultural policy \\
\hline
\end{tabular}


Appendix text A1.1. Full description of the scenarios

Gain over grain: local cash crops

Following international calls for agricultural development and national agricultural policy strategies, the Ethiopian government focuses on farmer commercialisation and specialisation as a pathway to increase economic returns and surplus production from smallholder agriculture. While in other parts of Ethiopia the focus is on food production, in the southwestern region farmers are encouraged to increase coffee production. Legal and environmental concerns prevent the government from also supporting other major cash crops, such as khat and fast-growing trees like Eucalyptus, but a lack of law enforcement and thriving markets have caused the expansion of these crops nevertheless. Actual crop choice often is rather opportunistic, and rapidly growing rural and urban populations further increase the demand for cash crops. Throughout the region, major investments have been made to improve road and railway infrastructure to allow market expansion and access.

The landscape now consists of large plots of intensively managed coffee forests interspersed with khat and tree plantations throughout the former farmland. The coffee forests are intensively managed, especially through regular clearing of undergrowth and heavy use of agrochemicals. While the coffee forests still provide some refuge to wild biodiversity, management practices have resulted in a stark loss of plant species and wildlife compared to the past. Khat plantations on former farmland are intensively managed as well. Tree plantations, most prominently monocultures of Eucalyptus, but also other fast-growing species such as Grevillea or Cupressus, are widespread, and in some places bamboo and native trees are also cultivated. The plantations of exotic species have severely impacted soil quality and lowered water tables in the landscape, which has made the area not only more susceptible to droughts but also made large areas unsuitable for agriculture. Farmland biodiversity has plummeted dramatically, because khat and tree plantations provide habitat to very few native species. Baboons and monkeys, however, still live in the forests and use farmland tree plantations for shelter; the animals' frequent raids of homegardens and small fields pose a serious problem to the remaining crops, especially for poor farmers who rely on their own food production. 
Live fences in the farmland protect the valuable cash crops from theft or destruction. Very little space remains for cultivating cereal crops, and few farmers have maintained small fields or homegardens for cereals. These small parcels for gardening and cropping are vital for the poor, because their lack of land and economic resources has excluded them from the cash crop boom and has limited their access to forest ecosystem services.

Overall, households have benefited from increased incomes and higher (material) living standards - almost all houses now have metal sheet roofs. Infrastructure and public services have improved, more children complete secondary school, and the overall population is becoming more educated. While many people are driven to emigrate from the southwest due to the growing population, increased education and knowledge have decreased population growth rates. Imported food from outside the region is now available at relatively cheap prices. Overall food security is high and people's diets now often include industrially processed foods including meat and dairy products. However, uncertainties remain in periods of drought and due to market price fluctuations. Social costs, in contrast, have been very high. There is a high degree of inequity, and poor people unable to seize cash crop opportunities are even poorer now. The increase in khat production also enhanced khat consumption leading to conflict, crime and a decline in community spirit. Theft of valuable cash crops is common, and there is a high degree of mistrust among the local community. The shift towards a cash-based society has led to the collapse of traditional institutions such as collaborative farming and guarding, and farmers now have to make large investments in human capital to manage and guard their cash crop plantations. Despite better health infrastructure, there are health problems caused by excessive khat consumption and the widespread use of pesticides, which affects food, air and freshwater quality.

\section{Mining green gold: coffee investors}

Ethiopia has shifted its focus towards large-scale commercial farming and the export of products to enhance agricultural development and national economic growth. Coffee is the primary export commodity. Due to climate change, there has been a global decline in the supply of coffee, and international demand and market prices for coffee have increased. Because of these conditions the government defined large-scale coffee production destined for the international market as the prime development priority for the region. Because the smallholder coffee production system is 
fragmented and because smallholders lack capital and institutional support to produce coffee for export, large-scale investors are given priority. Smallholder, communal and forestland conducive for coffee investment have been transferred to capital investors for the expansion of large-scale intensive coffee plantations.

The landscape is largely transformed to a coffee production zone, with monocultures of high yielding improved coffee cultivars. Large areas of natural forests and farmland have been converted into intensively managed shade coffee plantations, often using non-native shade tree species. Forest biodiversity and ecosystem services have declined rapidly, and it is becoming increasingly difficult for local people to access important forest products. Large-scale forest degradation and hybridisation with the new coffee varieties have destroyed the wild gene pool of Coffea arabica. As intensified coffee plantations have expanded into farmland, very little land is left for crop production. Local farmers are left to farm marginalised areas unsuitable for largescale coffee plantations such as on steep hills and in homegardens. Farmland biodiversity has decreased immensely as a result of the expansion of intensive coffee plantations. This has reduced smallholder farmer opportunities even further - for example, there are too few bees left for honey production. Furthermore, the increased use of agrochemicals for intensive coffee production and the expansion of coffee processing has led to polluted soils, groundwater, and rivers.

Due to the expansion of large-scale coffee plantations land has been transferred from local farmers to investors. Although farmers have been offered compensation for their farmland, this compensation has often been inadequate to make a living afterwards. Furthermore, community participation is tokenistic, and the investors do not live up to their initial promises of transferring skills, knowledge and technology to local communities. People's livelihoods have shifted from being subsistence-based towards employment as the major source of income. Employment opportunities mostly consist of daily labour at the coffee plantations. Job security is low, and often, jobs are given to non-locals. Infrastructure improvements have largely benefited investors, for example through better roads, while improvements in public services such as schools, health centres and other social services have been much more limited.

The transformation from semi-subsistence farming to large-scale coffee production has left many people landless, and vulnerable with little resilience to cope with shocks. The low wages received 
from labour have increased poverty among the local population. Decreased living standards and loss of land are causing major conflicts between local people and investors. Food security is mainly ensured through what can be purchased from the market. The low financial capital of people reduces dietary diversity and food security. Land scarcity, a general lack of opportunities, and a growing population, cause mass emigration from the countryside to towns, cities and countries abroad. Overall, social capital is very low. Traditional farming culture has been lost, and the majority of people have no idea how to cope with the change in livelihoods and population growth other than by leaving the area.

\section{Coffee and conservation: a biosphere reserve}

Years of conventional intensification supported by the green revolution have degraded natural resources throughout Ethiopia. Reduced soil fertility, large-scale soil erosion and persistent droughts made it impossible to grow enough food to feed the Ethiopian population. Due to pressure from environmental NGOs and local resistance to the failing strategy of conventional agriculture, the government has transformed its agricultural policy towards sustainable land management. Biosphere reserves are being established across Ethiopia to mainstream approaches that integrate conservation of natural habitat and sustainable food production. This shift was facilitated by increasing international demand for sustainably produced agricultural products, as well as the active participation of locals in the transformation process. In the southwest, the Buna Dhuga Biosphere Reserve has been established. This reserve emphasises not only the traditional culture of growing and drinking coffee, but also good social relationships, which are the central pillar of the newly established community-based management of the reserve.

The landscape consists of a core zone of unused natural forest, a buffer zone for low-intensity production of local coffee, wild honey, and other forest products, and an outer area with a mosaic of cropland, pastures and tree plantations. Planting of native tree species for timber, firewood and shade for coffee, is highly encouraged, and care is taken that people retain their uses and knowledge of local plants. The land is farmed using a mixture of traditional agricultural practices and modern techniques such as crop rotation, intercropping with legumes, soil and water conservation, and composting. Livestock production and communal grazing are maintained and also provide manure for fertilising the fields. People grow a wide variety of fruit and vegetables in 
their homegardens. Due to these sustainable practices, farmland biodiversity is recovering from earlier impacts of fertilisers and pesticides, and important ecosystem services provided by farmland, such as soil fertility, are restored.

The management of the biosphere reserve is realised through strong community participation, which also fostered the acceptance to establish a protected core zone of natural forests. Although some forest clearing was unavoidable to accommodate the growing population in the past, the core zone now is a haven for many rare and endangered species, and also is a refuge for the wild gene pool of Coffea arabica. To reduce negative impacts of wild crop-raiding animals, jobs as wildlife guards have been provided through community-based arrangements, especially to local people without access to land. The wildlife guards are responsible to help scare off crop-raiding animals, provide information to farmers on how to best protect fields, and where necessary reduce the populations of the most problematic species such as baboons and bush pigs via controlled culling measures. Community-based management of the reserve supports the continuation of semisubsistence farming and provides job opportunities for landless or poor people and minorities.

Social capital is high, and traditional collaborative agreements, such as didaro, have received renewed attention and have facilitated the transition process. Conflicts are usually solved within the community. Cultural integrity remains high and people are in good spirit. As an important part of their cultural identity, people grow and eat the majority of their own food. In addition, coffee and nature-based tourism are beginning to develop, bringing in extra money. The majority of people are now able to live in houses with metal roofs, have access to health and education, and are able to buffer their livelihoods during difficult times. Women in the region are empowered through inclusion in decision-making processes. This has led to higher acceptance of family planning and smaller family sizes, reducing population growth in the long-term. Despite limited economic growth, equality among people is high, and diversified farming combined with high social capital increases household resilience to climate change and other potential problems, such as market fluctuations or crop diseases.

\section{Food first: intensive farming and forest protection}

Due to climate change, coffee production has shifted to higher altitudes, and growing coffee has become unviable in most parts of southwestern Ethiopia due to frequent outbreaks of coffee pests 
and diseases. At the same time food production in the dryer parts of Ethiopia has seen a sharp decline due to increasingly frequent droughts. Given declining coffee production locally and stagnating food production in other parts of the country, the Ethiopian government declared the southwest a priority area for producing crops, fruit, vegetables, and beef. As a consequence, a rapid transition towards industrialised agriculture with high-yielding varieties and high agro-chemical input was realised. Modern agriculture almost completely replaced traditional small-scale farming and eroded local knowledge. The boost in land use intensity and efficiency required large-scale land consolidation, including the clearing of woody vegetation and cropland expansion. Flat areas including drained wetlands are now dominated by large cereal fields. The hills and steeper slopes are used for intensified fruit and vegetable production, commercial honey bee keeping and beef fattening. The transition of the farming system was facilitated by cooperatives that provided infrastructure for inputs, marketing and financial support. Farmers had to specialise and commercialise their production, now using large amounts of pesticides, artificial fertilisers, seeds and fodder. Local crops have been replaced by fast growing new varieties that require large amounts of pesticides and fertilisers. Farming has been mechanised as much as possible, with government-owned tractors being available for hire to work the larger stretches of cropland in the flat areas. The intensification of agriculture has led to a deterioration of natural capital in farmland, decreasing soil fertility even further, and hence increasing the dependence on external inputs and new crop varieties. Freshwater sources are polluted from agrochemicals. Virtually everything harvested is sold to markets. Storage facilities and processing plants have been set up in the larger towns.

To limit further expansion of farmland, to reduce potential impacts of climate change and to satisfy international pressure for nature protection, the remaining patches of natural forest are put under strict protection. The resulting protected areas have been partially fenced to limit illegal forest use but also to reduce crop raiding from wild animals. Despite strict protection, the fragmentation and isolation of remnant forest patches has led to further decreases in forest biodiversity. Large-scale deforestation combined with intensification of agriculture has led to widespread soil erosion, which the government now tries to tackle by building dams and water channels.

Large-scale land consolidation has increased overall inequality in the region, and left many people without access to land. While farmers who managed the transition and received land are relatively 
well off, others remain poor. Some managed to get employment on other people's farms, but opportunities are limited because of high levels of mechanisation and a focus on efficiency. Other people have emigrated to towns in an attempt to make a living by working in one of the many food processing factories. With modernisation, individualistic behaviour has increased, and cultural identity and community cohesion have been eroded. People now mainly eat purchased and processed food, including processed meat and dairy products imported from elsewhere. Dietary diversity no longer comes from diversified cropping, but depends on what is available and affordable on the market. Due to specialisation and commercialisation, the resilience of farmers is primarily based on financial capital. However, due to crop specialisation and the loss of many ecosystem services, farmers are not resilient to climate change, and, despite increased financial capital, some are forced into debt after unfavourable years with low harvests. Moreover, people are strongly affected by market price fluctuations to sell harvests and buy food, which further decreases their resilience. Population growth remains high, particularly among the poor. Many of the poor emigrate to towns and cities, putting additional pressure on increasingly large urban slums. 